\title{
A severe form of maternal separation in rat consisting of nineteen-day 6-hour daily separation at unpredictable times minimally affects behavior across the lifespan
}

\author{
Tatyana B. Behring (iD) 1,2 , Margaret H. Kyle (D) 1,2,3, Maha Hussain ${ }^{3}$, Jack Y. Zhang ${ }^{3}{ }^{3}$, Alessia Manganaro ${ }^{3}$, Jasmine H. \\ Kaidbey (DD 1,2 , Robert J. Ludwig ${ }^{1,2}$, Michael M. Myers ${ }^{1,2}$, Martha G. Welch (iD) 1,2 , and Dani Dumitriu (DD $1,2,3,4 \bowtie$ \\ ${ }^{1}$ Division of Developmental Neuroscience, Department of Psychiatry, Columbia University Irving Medical Center, New York, NY, 10032, USA. \\ ${ }^{2}$ Nurture Science Program, Department of Pediatrics, Columbia University Irving Medical Center, New York, NY, 10032, USA. \\ ${ }^{3}$ Division of Child and Adolescent Health, Department of Pediatrics, Columbia University Irving Medical Center, New York, New York, NY, 10032 , USA. \\ ${ }^{4}$ Sackler Institute for Developmental Psychobiology, Columbia University, New York, NY, 10032, USA.
}

\begin{abstract}
Maternal separation (MS), a type of early life stress, has been associated with adverse socioemotional and behavioral outcomes throughout the lifespan across multiple species. Comprehensive longitudinal biobehavioral characterization of MS in rats is sparse and conflicting, warranting more studies. We conducted an MS paradigm involving 6-hour daily separation at unpredictable start times from P2 to P21. We hypothesized this severe form of MS would lead to developmentally emerging maladaptive biobehavioral consequences from juvenile through adult periods compared to Controls $(\mathrm{C})$, especially in social behaviors. We tested: (1) own dam odor preference shortly after weaning; (2) juvenile and adult anxiety-like, sociability, and play behaviors using the light-dark test, three-chambered social interaction test, and video-coded juvenile play behavior; and (3) adult coping behaviors and neuroendocrine response using the forced swim test and blood corticosterone responses. Our results show minimal effects on biobehavioral outcomes across the lifespan. Recently weaned MS male rats had a stronger preference for their dam's odor. Juvenile MS females spent more time in rough-and-tumble play than $\mathrm{C}$ female rats. No differences in sociability were found in the juvenile or adult periods. MS promoted a decrease in anxiety-like behavior that persisted from juvenile to adult periods. Finally, MS led to deficits in coping behavior in male adults, but basal and reactive corticosterone levels were unaltered by MS. More studies are needed to validate our surprising findings and probe the neural mechanisms underlying some of the observed protective effects.
\end{abstract}

Correspondence: dani.dumitriu@columbia.edu

\section{Significance Statement}

Maternal separation (MS), a type of early life stress, has been shown to lead to short and long-term adverse socioemotional consequences in humans and biobehavioral outcomes in rodents. Available data on MS exposed rats are sparse, conflicting, and often lack longitudinal outcomes. We designed a 6-hour unpredictable daily MS paradigm from postnatal day (P2) to P21 to severely disrupt normal dam-pup interactions. Our results show MS leads to increased preference for own dam odor, persisting reductions in anxiety-like behaviors from juvenile to adulthood, and no effects on sociability. Adverse effects on coping behaviors were uniquely identified in males. The present study warrants reevaluation of the central dogma that MS leads to maladaptive biobehavioral outcomes.

\section{Introduction}

Early postnatal development is important in determining future socioemotional outcomes. In this period, infants are sensitive to the "loss" of- the mother (Bowlby, 1970, 1982; Hofer, 1996; Welch, 2016; Ludwig and Welch, 2019), and maternal deprivation is broadly classified as an early life stress (Molet et al., 2014; Welch, 2016). Maternal separation (MS) and/or deprivation in humans is associated with adverse socioemotional outcomes in childhood (Kaler and Freeman, 1994; Chisholm, 1998; Chugani et al., 2001), adolescence (Kreppner et al., 2007; Beverly et al., 2008; Stevens et al., 2008; Shin et al., 2016; Pesarico et al., 2017) and adulthood (Mozaffari, 2018). Parallel findings have been reported in rodents (Kalinichev et al., 2002; Romeo et al., 2003). Given MS-mediated adverse outcomes are observed across the lifespan in both humans and rats, this model is critical for identifying mechanisms of early life stress and possible therapeutic strategies for treatment and/or prevention.

The MS paradigm is typically comprised of daily 3-hour separations, but longer separations between rodent dams and pups during the first two weeks of life are also used (Baudin et al., 2012; Xue et al., 2013; Zhang et al., 2013; Lundberg et al., 2017b). The dam's care for her pups has been shown to mediate many physiological processes such as feeding, nipple attachment, and heart rate (Hofer, 1983; Myers et al., 1989; Kentrop et al., 2018). The disruption of normal interactions by MS and its acute negative effects on these physiological processes have been studied for many years (Hofer and Weiner, 1971; Hofer, 1975; Ranger et al., 2021). Longerterm adverse effects have been associated with impaired social functioning (Kambali et al., 2019),, but more frequently with increases in stress responses, anxiety-, and depressivelike behaviors in both dams and pups, as well as increases in corticosterone levels (Stanton et al., 1988) and altered HPA activation in MS pups (Liu et al., 1997; Caldji et al., 2000; Kalinichev et al., 2002; Maniam and Morris, 2010). In contrast, other studies have demonstrated that MS can promote resilience or have few long-term consequences (Lundberg et al., 2017a; Kambali et al., 2019). These conflicting findings and the lack of emphasis on social outcomes warrants further investigation of the paradigm (Lehmann et al., 2000).

Previously, our group demonstrated altered patterns of 
ultrasonic vocalizations (Kaidbey et al., 2019) and blunted pup fronto-cortical activity during normal in-cage dam-pup interactions (Ranger et al., 2021) in a 3-hour, 10-day MS rat model. In the current study, we sought to establish the effects of a severe form of MS on long-term biobehavioral outcomes in rats. We used a 6-hour daily MS paradigm with an unpredictable start time and isolation from both dam and littermates from postnatal day (P) 2 through P21 in rats (D'Agata et al., 2017). We compared MS-reared animals to standard animal facility reared controls (C) to test for effects of MS biobehavioral outcomes across the lifespan. To assess this, we examined (1) own dam odor preference shortly after weaning; (2) juvenile and adult anxiety-like, sociability, and play behaviors using the light-dark (LD) test, threechambered social interaction test (SIT, and video-recorded juvenile play behavior; and (3) adult coping behaviors and neuroendocrine response using the forced swim test (FST) and blood corticosterone responses. To the best of our knowledge, this study represents the first rigorous approach to elucidating the effects of early life stress on long-term biobehavioral consequences in a severe form of rat MS.

\section{Methods}

\section{Subjects}

Sixteen timed-pregnant Sprague Dawley dams from Charles River (Wilmington, MA) were received on E17 and housed in the New York State Psychiatric Institute rat colony facility. Animals were kept in a 12-hour dark/light cycles with lights on at $7 \mathrm{am}$ in a temperature $\left(21^{\circ} \mathrm{C}\right)$ and humidity controlled (40\%) room, with food and water available ad libitum and routine husbandry provided. The dams were checked daily to determine the precise day of birth (postnatal day $0, \mathrm{P} 0$ ). On P2, litters were culled to 8 with a 1:1 male: female ratio when possible. All procedures were conducted strictly following animal protocols approved by Columbia University Irving Medical Centre and New York State Psychiatric Institute's Institutional Animal Care and Use Committees.

A total of 104 (1:1 male:female) of 128 rats were selected randomly to be used in the study. All litters $(n=16$ [control=8, maternally separated $=8]$ ) were weaned on P21 and transferred to a new cage with 2 rats per cage. A smaller portion of rats $(n=40[\mathrm{C}=20, \mathrm{MS}=20,1: 1$ male:female $])$ was randomly assigned to a cross-housed condition in which they were housed with rats reared differently (control with maternally separated offspring). The rest of the rats were housed with siblings from the same litter $(\mathrm{n}=64(\mathrm{C}=32, \mathrm{MS}=32$ [1:1 male:female])). Of these rats, $24(\mathrm{C}=12, \mathrm{MS}=12,1: 1$ male:female) were randomly assigned to a non-tested group, which would not undergo juvenile testing. A flow chart of the study procedures can be found in Figure 1 as well as the weights of the animals.

\section{Maternal separation procedure}

From P2 to P21, the maternal separation pups (MS group, 8 litters, 64 pups) were each isolated in cylindrical PVC partitions inside a new cage with fresh bedding (one pup per cylinder, 8 cylinders per cage, Fig. 1A), as previously described in Kaidbey (Kaidbey et al., 2019) and Ranger (Ranger et al., 2021). Pups were separated from their mothers and siblings at randomly selected starting times that were 1.5 hour apart during the light phase of the cycle between 7:30 AM and 12:30 PM (i.e., 7:30, 9:00, 10:30, 11:00, 12:30) for 6 hours a day. The dams were also placed into new cages with food and water available ad-libidum. After the separation period the pups were returned to their home-cage followed by the dam. Pups in the control group remained with their mother until weaning at P21, except for handling once a week for routine husbandry. Pup weight was measured on P21 and P85.

\section{Testing Procedures}

Pups were weaned at P21. Half were co-housed with one same-sex sibling (sibling-housed group) and half with one individual from another litter (cross-housed group). MS animals were co-housed with control animals in the latter situation. Of the 128 pups that were weaned, 104 of those were randomly chosen to be tested. Ultimately, 80 rats from 40 pairs were selected randomly for juvenile behavioral testing and were a part of the "tested group", while 104 completed adult behavioral testing and included both "tested" and "untested" animals. The "untested" rats did not undergo LD testing during the juvenile period, but did undergo play behavioral testing, since this was minimally stressful and involved their own cage-mates.

\section{Maternal odor preference test (OP)}

The OP test used a 3-chambered box with dimensions $42 \times$ $62 \times 30 \mathrm{~cm}^{3}$ (custom made, Curbell Plastics, Orchard Park, NY, USA), and cylindrical interactors, with outer diameters of $10 \mathrm{~cm}$ and heights of $25 \mathrm{~cm}$. The 2 peripheral chambers were separated from the middle section with boards that had $10 \mathrm{~cm}$ wide slots for rat movement between chambers. Dam odor was allowed to accumulate in the cage for the first 24 hours of after weaning and was placed into satchels that were placed into the cylindrical interactors. The location of the unfamiliar dam odor was alternated with each experiment to avoid place-preference. Animals were initially placed in the apparatus for a 5-minute habituation period without the presence of any odor. Pups were then removed so that pouches with maternal and unfamiliar dam's odors (10 $\mathrm{g}$ of bedding) could be added in the cylinders. They were then placed in the box again for a 10-minute testing period. The interactors and chambers were thoroughly cleaned with Virkon S solution in between trials.

\section{Play behavior}

Play was assessed at four different points during the juvenile period to examine how behavior progressed as pups aged. One hour before play behavior was tested the pups were separated from each other in new cages. After the separation, pups were reunited in a dark room to promote play behavior in a clean test cage of dimensions $19 \times 10 \mathrm{in}^{2}$. Pups were placed in the center of the cage with their cage-mate and behavior was video-recorded for 10 minutes. 
A

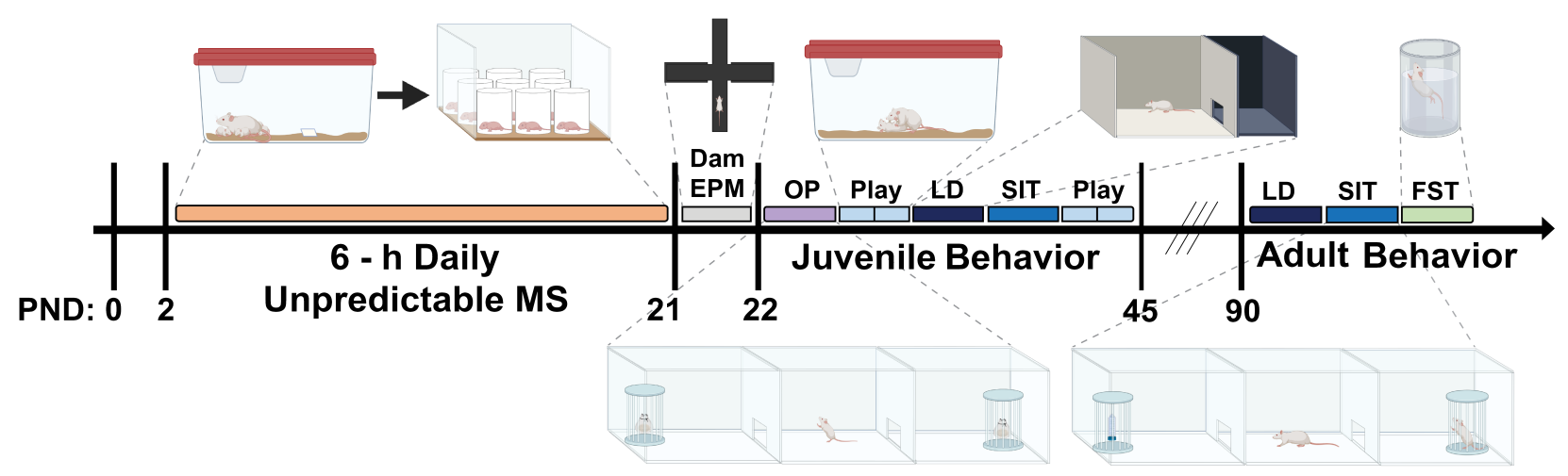

B

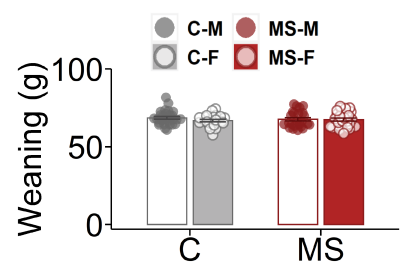

Weight

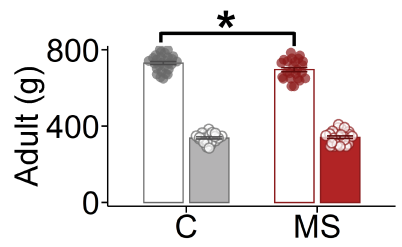

C

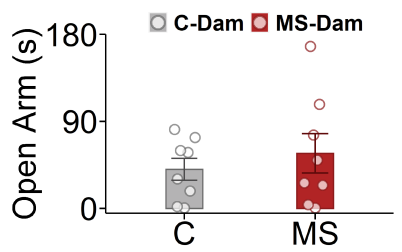

Dam Elevated Plus Maze

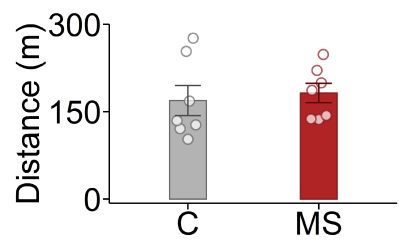

Fig. 1. Figure 1. A severe maternal separation (MS) model designed to induce maximal biobehavioral consequences throughout the lifespan. (A) Pup births were monitored to establish P0. The 6-h daily unpredictable MS began on P2 and lasted until P21. Pups were separated from their dam and littermates and placed in cylinders for the duration of the 6-hour period. On P21, pups were weaned and dam anxiety was tested on the elevated plus maze (EPM) test. Starting on P22 juvenile behavioral testing began and included maternal odor preference (OP), light-dark box test (LD), social interaction test (SIT) and repeated testing of play behavior. Starting on P90, adult behavioral testing began and included LD, SIT, and forced swim test (FST). (B) Weaning (left) and adult (right) weights. No weight effects were observed at weaning (Rearing: $F_{1,99}=0.013, p=0.91$, Sex: $F_{1,99}=1.10, p=0.30$, Rearing $\times$ Sex: $F_{1,99}=0.68, p=0.41$ ); As expected, a sex effect was observed in adult rats, with males weighting significantly more than females (Sex: $F_{1,98}=2233, p=2.92 \times 10^{-69}$ ). Interestingly, while no rearing effect was observed, a significant rearing by sex effect was seen, with MS males, but not females, weighting slightly less (Rearing: $F_{1,98}=3.63, p=0.60$, Rearing $\times$ Sex $F_{1,98}=5.82$, $p=0.018$, Tukey's, $p=0.012$ ). (C) No significant differences were observed in EPM open arm time (Open Arm (s), $t(10.9)=-0.708, p=0.49)$ (left) or total distance travelled (Distance $(\mathrm{m}), t(10.2)=-0.416, p=0.69)$ (right) in MS versus $\mathrm{C}$ dams immediately post-weaning. Bars represent means $\pm \mathrm{SEM}$. ${ }^{*} p<0.05$ on Tukey's Test.https://www.overleaf.com/project/60bbd38d4716625e076a5b9e

\section{Light-dark box test (LD)}

For the LD test, rats were placed first in the light compartment of a two chambered custom-made apparatus (custom made, Curbell Plastics, Orchard Park, NY, USA) The juvenile apparatus (Plexiglas) was $16 \times 40 \times 21 \mathrm{~cm}^{3}$ and the adult apparatus (acrylic) was $100 \times 100 \times 40 \mathrm{~cm}^{3}$. The animals were allowed to freely explore both compartments for 5 -minutes as previously described (Costall et al., 1989; Arrant et al., 2013). The time spent (Light Time, s) and distance travelled (Light, $\mathrm{m}$ ) in the light compartment, the frequency of entering the light compartment (Light Entries, \#), and the latency to enter the dark (Lat to Dark, s) compartment were analyzed using video-recordings in Ethovision. The apparatus was cleaned with Virkon $\mathrm{S}$ between trials.

\section{Social interaction test (SIT)}

The SIT (Kaidanovich-Beilin et al., 2011) was performed in a custom-made 3-chambered social interaction apparatus (custom made, Curbell Plastics, Orchard Park, NY, USA; juvenile apparatus: white acrylic $42 \times 62 \times 30 \mathrm{~cm}^{3}$; adult apparatus: black acrylic $80 \times 120 \times 40 \mathrm{~cm}^{3}$ ). Rats were tested to deter- mine their preference for a novel rat versus a novel object. Each was placed inside a cylinder with wired grid/mesh (juvenile interactors: $10 \mathrm{~cm}$ outer diameter, $25 \mathrm{~cm}$ height; adult interactors: $25 \mathrm{~cm}$ outer diameter, $25 \mathrm{~cm}$ height). Rats were first placed inside the center chamber and left to freely explore the entire apparatus with empty interactors located in the peripheral compartments for a 5-minute habituation period. Animals were then temporarily removed from the apparatus so that a novel rat and object could be placed inside the interactors. Placement of the novel rat or novel object were alternated between trials. Rats were then placed again in the central box of the apparatus and tested for 10-minutes. The box was cleaned with Virkon S between trials.

\section{Forced swim test (FST)}

Adult animals $(\sim \mathrm{P} 150)$ were tested in a two-day FST paradigm as described elsewhere (Slattery and Cryan, 2012; Yankelevitch-Yahav et al., 2015). The experiment consisted of an initial 15-minute training (pre-test) session on day 1, and a 5-minute testing session 24 hours later. A clear, Plexiglas container (custom made, Curbell Plastics, Orchard Park, 
bioRxiv preprint doi: https://doi.org/10.1101/2021.06.07.447289; this version posted June 7, 2021. The copyright holder for this preprint (which was not certified by peer review) is the author/funder, who has granted bioRxiv a license to display the preprint in perpetuity. It is made available under aCC-BY-NC-ND 4.0 International license.

A

\section{Maternal Odor Preference}

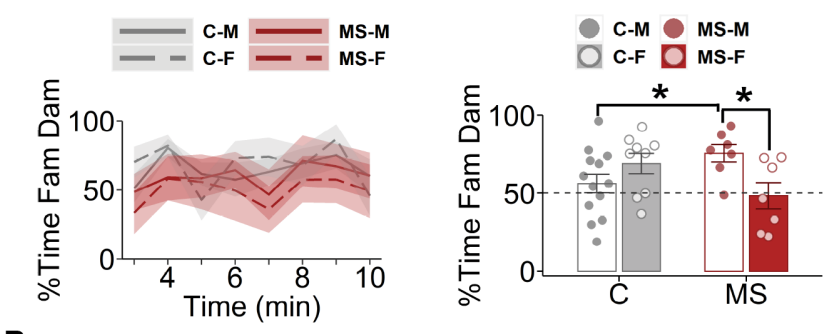

B

Social Interaction
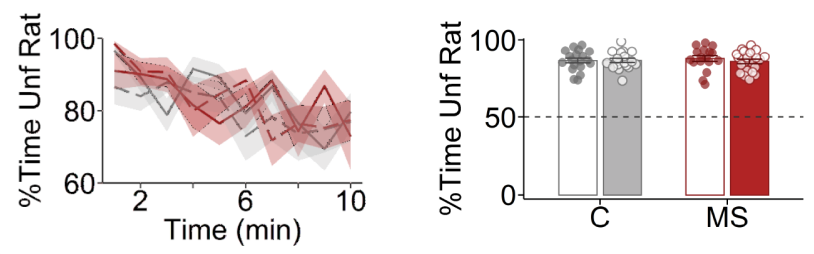

C

\section{Juvenile Play Behavior}
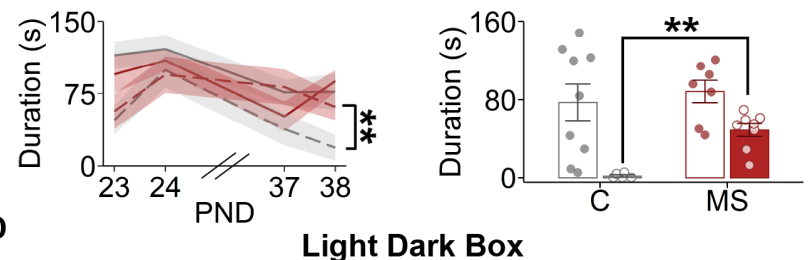

Light Dark Box
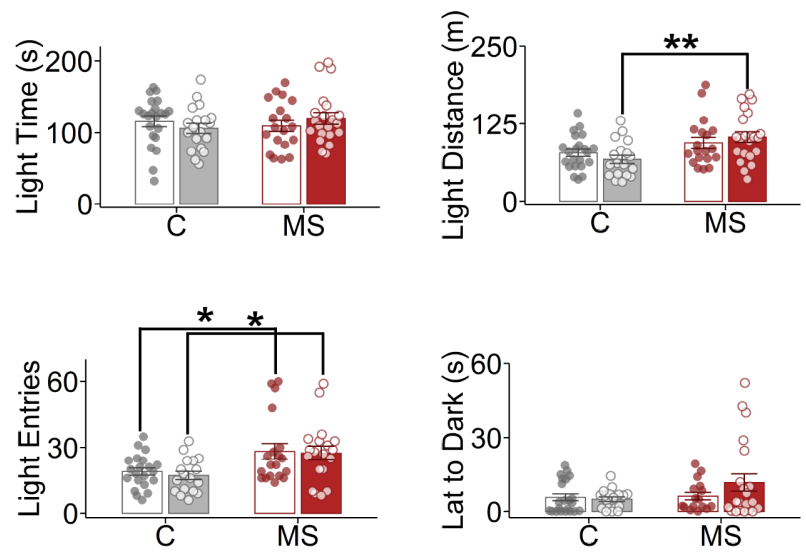

Fig. 2. Effect of MS on maternal odor preference, juvenile sociability, and anxiety-like behavior. (A) Maternal odor preference was tested by presentation of the pup's own dam's odor versus an unfamiliar dam odor in a three-chamber arena. Data was analyzed for the last 8 min of 10 min of exploration. No significant differences were observed in 1-min binned time-series (left:\% Time Fam Dam, Rearing: $F_{1,25}=1.67, p=0.21$, Sex: $F_{1,25}=0.16, p=0.69$, Time $: F_{7,175}=0.91, p=0.50$, Rearing $\times$ Sex: $F_{1,25}=0.246, p=0.624$, Rearing $\times$ Time: $F_{7,175}=1.36, p=0.23$, Sex $\times$ Time: $F_{7,175}=0.29, p=0.96$, Rearing $\times$ Sex $\times$ Time: $F_{7,175}=1.03$, $p=0.41$ ), but cumulatively, MS males did spent more time with their own dam's odor than C males (right: \% Time Fam Dam, Rearing: $F_{1}, 32=0.008, p=0.93$, Sex: $F_{1,32}=1.09, p=0.31$, Rearing $\times$ Sex: $\left.F_{1,32}=8.38, p=0.007\right)$. (B) ) No significant group differences were seen in the SIT over time (left: \% Time Unf Rat, Rearing: $F_{1,67}=0.70, p=0.40$, Sex: $F_{1,67}=0.99, p=0.32$, Time: $F_{9,603}=4.93, p=2.1 \times 10^{-6}$, Rearing $\times$ Sex: $F_{1,67}=0.44, p=0.51$, Rearing $\times$ Time: $F_{9,603}=1.21$, $p=0.29$, Sex $\times$ Time: $F_{9,603}=0.99, p=0.45$, Rearing $\times$ Sex $\times$ Time $: F_{9,603}=1.17, p=0.31$ ) or cumulatively (right: \% Time Unf Rat, Rearing: $F_{1,71}=0.036$, $p=0.85$, Sex: $F_{1,71}=0.34, p=0.56$, Rearing $\times$ Sex: $\left.F_{1,71}=0.41, p=0.53\right)$. C Repeated-measures ANOVA on the duration of time spent engaging in play behavior revealed an interaction between Rearing and Sex, which post-hoc testing showed to be driven by more play behavior in the MS females compared to $\mathrm{C}$ females on the last day of testing (left: Duration (s), Rearing: $F_{1,25}=1.58, p=0.22$, Sex: $F_{1,25}=26, p=2.9 \times 10^{-5}$, Time: $F_{3,75}=7.24, p=2.5 \times 10^{-4}$, Rearing $\times$ Sex: $F_{1,25}=8.42$, $p=0.008$, Rearing $\times$ Time: $F_{3,75}=0.77, p=0.51$, Sex $\times$ Time: $F_{3,75}=1.73, p=0.17$, Rearing $\times$ Sex $\times$ Time: $F_{3,75}=0.56, p=0.64$ ). An analysis of the last day alone confirmed this effect (right: Duration (s), Rearing: $F_{1,25}=4.36, p=0.047$, Sex: $F_{1,25}=17.1, p=3.5 \times 10^{-4}$, Rearing $\times$ Sex: $F_{1,25}=1.65, p=0.21$ ). DLight dark box testing revealed less anxiety-like behavior in MS rats on several measures: light time (top left: Light Time (s), Rearing: $F_{1}, 77=0.24, p=0.63$, Sex: $F_{1,77}=7.0 \times 10^{-4}, p=0.98$, Rearing $\times$ Sex: $F_{1,77}=1.70, p=0.19$ ), distance travelled in the light zone (top right: Light Distance (m), Rearing: $F_{1,76}=11.3$, $p=0.001$, Sex: $F_{1,76}=0.007, p=0.94$, Rearing $\times$ Sex: $F_{1,76}=1.71, p=0.20$ ), light transitions or entries (lower left: Light Entries, Rearing: $F_{1,76}=11.3$, $p=0.001$, Sex: $F_{1,76}=0.007, p=0.94$, Rearing $\times$ Sex: $F_{1,76}=1.71, p=0.20$ ), latency to enter the dark zone (lower right: Lat to Dark (s), Rearing: $F_{1,73}=2.65$, $p=0.11$, Sex: $F_{1,73}=1.13, p=0.29$, Rearing $\times$ Sex: $F_{1,73}=1.99, p=0.16$ ). Fam, familiar; Unf, unfamiliar; Lat, latency; Light, light zone; Dark, dark zone; MS, maternally separated; $\mathrm{C}$, control. Bars represent means \pm SEM. Lines represent means. Shaded regions represent SEM. (Tukey's or Bonferroni's tests, ${ }^{*} p<0.05$, $\left.{ }^{* *} p<0.01\right)$. 
bioRxiv preprint doi: https://doi.org/10.1101/2021.06.07.447289; this version posted June 7, 2021. The copyright holder for this preprint (which was not certified by peer review) is the author/funder, who has granted bioRxiv a license to display the preprint in perpetuity. It is made available under aCC-BY-NC-ND 4.0 International license.

NY, USA) with an internal diameter of $20 \mathrm{~cm}$ and a height of $50 \mathrm{~cm}$ was filled with tap water at a temperature of $24 \pm 1^{\circ} \mathrm{C}$, to a height such that the animal was unable to touch the bottom with its hind paws $(35 \pm 1 \mathrm{~cm})$. After each trial, animals were dried with a towel by the experimenter and then placed in a clean holding cage atop a heating pad set to $37^{\circ} \mathrm{C}$. Animals were reintroduced to their home cage when completely dry.

\section{Blood collection during FST for corticosterone}

Each animal underwent blood draws at five distinct time points: immediately prior to the FST (time 0), and at 15 minutes, 30 minutes, 60 minutes, and 120 minutes post-FST. Blood was obtained via tail clipping and 20 to $100 \mu \mathrm{L}$ at each time point was collected into a capillary tube with heparin (Microvette ${ }^{\circledR} 100$ K3E, EDTA Preparation, Sarstedt). The tube was immediately placed on ice. Serial samples of blood were collected at post-FST time points by manual disruption of the clot at the end of the tail. Pressure was applied to the wound for hemostasis. When blood flow was heavier than anticipated, styptic powder was applied. Following completion of the behavioral paradigm, the tubes were centrifuged at $5000 \mathrm{RPM}$ for 10 minutes, in a $4^{\circ} \mathrm{C}$ cold room. The supernatant was then separated from the pellet with a pipette, and stored at $-20^{\circ} \mathrm{C}$ for subsequent steroid analysis.

\section{Elevated plus maze (EPM)}

Dams were tested in a standard plus-shaped EPM apparatus (custom made, Curbell Plastics, Orchard Park, NY, USA), consisting of two open arms and two closed arms of the same size $\left(50 \times 10 \mathrm{~cm}^{2}\right)$ joined by a closed center square. The closed arms were enclosed by walls $(35 \mathrm{~cm})$ except at the joined platform. The entire apparatus was elevated to a height of $55 \mathrm{~cm}$ above the floor. Rats were placed individually at the center of the open field facing one of the open arms and were allowed to explore the apparatus for 10 minutes. The time spent in the open arms, number of entries into the open arms, and distance were measured. The EPM was cleaned with Virkon $\mathrm{S}$ between trials.

\section{Behavioral analysis}

Behavioral data were collected using a high-definition webcam (C920, Logitech, Apples, Switzerland) or an infrared camera (EO-2223 NIR USB 3.0 Camera, Edmund Optics, Barrington, NJ, USA, 08007) when the behavior was conducted under infrared illumination (AT-11E-S 80, Axton Tech, North Salt Lake, UT 84054). Play behavior including durations (seconds) of rough-and-tumble (rolling around) was coded manually by an observer blind to the treatment groups using Avidemux software (version 2.7.4, http://www.avidemux.org) and Microsoft Excel. All other behaviors were analyzed with Ethovision XT software (version 15; Noldus Information Technology, Wageningen, the Netherlands), with the exception of climbing behavior in the FST, which was manually scored by an observer blind to the group and sex of the rat.
A

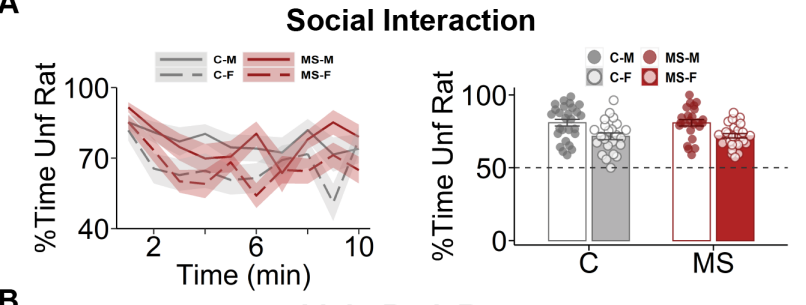

B

Light Dark Box
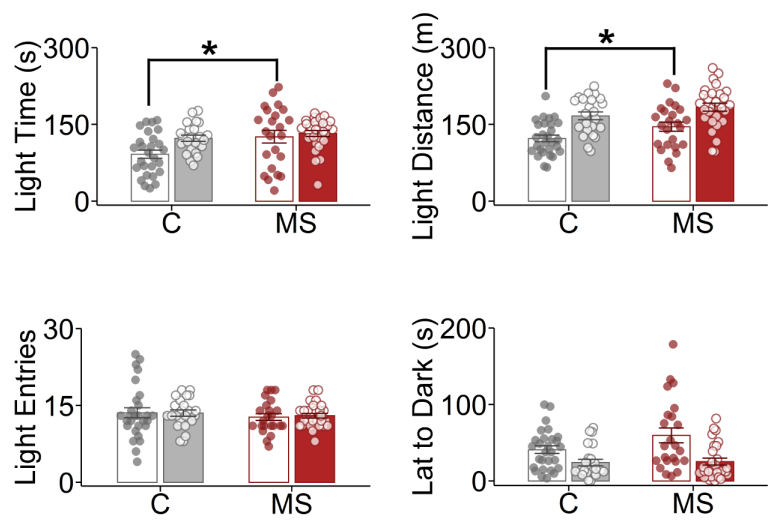

Fig. 3. Effect of MS on adult sociability and anxiety-like behavior mostly mirror juvenile phenotypes. (A) No effects of MS were observed on SIT though significant Sex effects were observed both in time series analysis (left: \% Time Unf Rat, Rearing: $F_{1,91}=0.011, p=0.92$, Sex: $F_{1,91}=21, p=1.8 \times 10^{-5}$, Time: $F_{9,819}=4.31, p=1.7 \times 10^{-5}$, Rearing $\times$ Sex: $F_{1,91}=0.012, p=0.92$, Rearing $\times$ Time: $F_{9,819}=1.82, p=0.62$, Sex $\times$ Time: $F_{9,819}=1.28$, $p=0.24$, Rearing $\times$ Sex $\times$ Time: $\left.F_{9,819}=0.73, p=0.68\right)$ and cumulative time spent with an unfamiliar rat (right: \% Time Unf Rat, Rearing: $F_{1,98}=0.004$, $p=0.95$, Sex: $F_{1,98}=18.9, p=3.3 \times 10^{-5}$, Rearing $\times$ Sex: $F_{1,98}=0.014$, $p=0.91$ ), with males spending more time in social exploration than females (Tukey's $p=2.7 \times 10^{-5}$ ). (B) Light dark box testing revealed significant effects of Rearing, with MS males spending more time and traveling a longer distance in the light zone than $\mathrm{C}$ males, and Sex, with females having shorter latency to the dark zone, but spending more time in, traveling longer distance in, and showing more transitions to the light zone. (top left: Light Time (s), Rearing: $F_{1,97}=6.90$, $p=0.01$, Sex: $F_{1,97}=5.14, p=0.026$, Rearing $\times$ Sex: $F_{1,97}=2.26$, $p=0.14$; top right: Light Distance $(\mathrm{m})$, Rearing: $F_{1,99}=6.76, p=0.011$, Sex: $F_{1,99}=29, p=5.1 \times 10^{-7}$, Rearing $\times$ Sex: $F_{1,99}=0.15, p=0.70$; lower left: Light Entries, Rearing: $F_{1,97}=0.86, p=0.36$, Sex: $F_{1,97}=0.021$, $p=0.89$, Rearing $\times$ Sex: $F_{1,97}=0.045, p=0.83$; lower right: Lat to Dark (s), Rearing: $F_{1,97}=2.70, p=0.10$, Sex: $F_{1,97}=17.7, p=5.7 \times 10^{-5}$, Rearing $\times$ Sex: $F_{1,97}=2.05, p=0.16$ ). Fam, familiar; Unf, unfamiliar; Lat, latency; Light, light zone; Dark, dark zone. Bars represent means \pm SEM. Lines represent means. Shaded regions represent SEM. (Tukey's or Bonferroni's tests, ${ }^{*} p<0.05$, $\left.{ }^{* *} p<0.01\right)$.

\section{Statistical Analysis}

Data manipulation and graphing were performed in $\mathrm{R}$ using the stringr, outliers, ggplot2, and dplyr libraries while statistical analyses were done using the rstatix package. A $2 \times 2 \times 2$ ANOVA was used to analyze the effects of Rearing, Sex and Housing or Rearing, Sex, and Testing. A repeated measures ANOVA was used to analyze time course data. Planned post-hoc comparisons were conducted using Tukey's Test or Bonferroni's correction to alpha for multiple, repeated measures tests. A two-tailed t-test was used to analyze EPM data. For corticosterone analyses, obtained absorbance data were analyzed in GraphPad Prism 8.0, where the serum corticosterone concentrations $(\mathrm{ng} / \mathrm{ml})$ were $\log$ transformed and a two-way analysis of variance (ANOVA) 
bioRxiv preprint doi: https://doi.org/10.1101/2021.06.07.447289; this version posted June 7, 2021. The copyright holder for this preprint (which was not certified by peer review) is the author/funder, who has granted bioRxiv a license to display the preprint in perpetuity. It is made available under aCC-BY-NC-ND 4.0 International license.

with Bonferroni’s post-hoc test applied.

\section{Results}

\section{A severe form of MS designed for maximal effects on biobe-} havioral profiles across the lifespan

Six-hours of maternal separation began on $\mathrm{P} 2$ and lasted until P21 (Fig. 1A). A total of $104(\mathrm{C}=52, \mathrm{MS}=52,1: 1$ male:female) rats were used in the study. Of these rats, 40 $[\mathrm{C}=20, \mathrm{MS}=20,1: 1$ male:female]) was randomly assigned to a cross-housed condition (control with maternally separated offspring). The remaining 64 rats were housed with siblings from the same litter $(\mathrm{C}=32, \mathrm{MS}=32,1: 1$ male:female). Of this group, 24 rats $(C=12, M S=12,1: 1$ male:female) were randomly assigned to a non-tested group, which would not undergo juvenile testing. There were a total of 12 groups of rats across rearing, sex, housing, and testing conditions. Pup body weight was assessed at weaning (P21) and consistent with our previous results (Kaidbey et al., 2019), no significant differences in body weight between $\mathrm{C}$ and MS groups for either males or females was identified despite the prolonged separation (Fig. 1B). Interestingly, while there was also no effect of MS on the weight in adults ( $\sim$ P90), a rearing by sex interaction was identified with MS males weighting slightly less than their $\mathrm{C}$ counterparts. Furthermore, we assessed dam anxiety on the EPM test and found no differences on between MS and C dams (Fig. 1C).

\section{MS minimally affects juvenile behaviors and when it does, it is associated with protection against maladaptive behav- iors}

We first asked whether this severe form of MS reduces the pups' preference for their own dam's odor. The maternal odor preference (OP) test was conducted 1-4 days post-weaning (P22 to P25). We selected this time interval to allow the dam odor to accumulate in the newly changed cage after weaning and to impregnate the bedding to be used for the test. A 3-chambered arena was used with one side-chamber containing the juvenile's own dam odor and the other side-chamber containing an unfamiliar dam odor. During the first 2-min all pus investigated the two odor-containing chambers equally. Therefore, we considered this to be a habituation period and focused analyses on the remaining 8 minutes of the test (Fig. 2A, left).

We found no significant differences between groups on repeated measures ANOVA on 1-min binned exploration (Rearing: $F_{1,25}=1.67, p=0.21$, Sex: $F_{1,25}=0.16$, $p=0.69$, Time: $F_{7,175}=0.91, p=0.50$, Rearing $\times$ Sex: $F 1,25=0.25, p=0.62$, Rearing $\times$ Time: $F_{7,175}=1.36$, $p=0.23$, Sex $\times$ Time: $F_{7,175}=0.29, p=0.96$, Rearing $\times$ Sex $\times$ Time: $\left.F_{7,175}=1.03, p=0.41\right)$. However, a $2 \times 2$ ANOVA on cumulative exploration during the 8 min revealed a significant interaction between Rearing and Sex (Rearing: $F_{1,32}=0.008, p=0.93$, Sex: $F_{1,32}=1.09$, $p=0.31$, Rearing $\times$ Sex: $F_{1,32}=8.38, p=0.007$ ) (Fig. $2 \mathrm{~A}$, right), with MS male but not female pups spending significantly more time investigating their own dam's odors compared to both C males (Tukey's $p=0.049$ ) and MS female
A
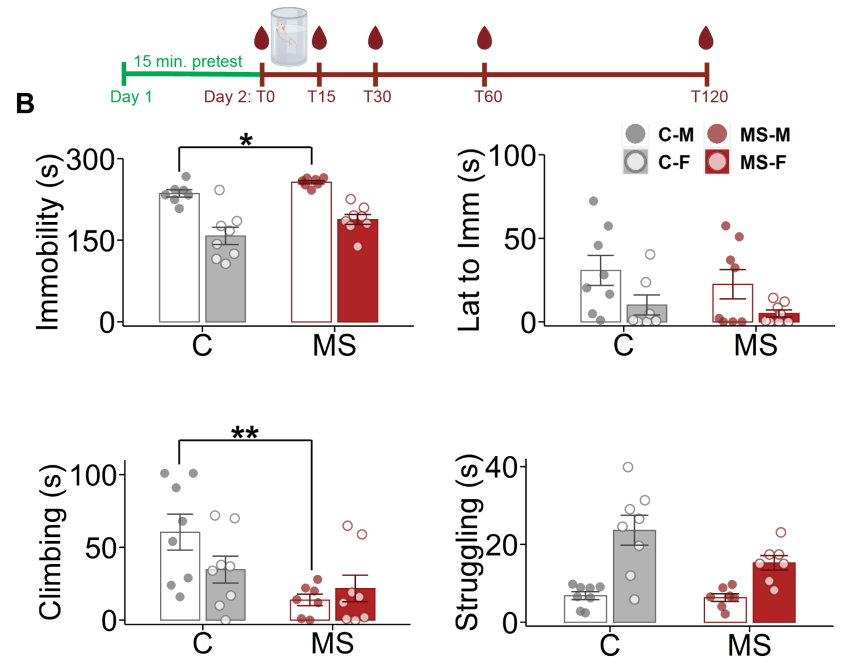

C
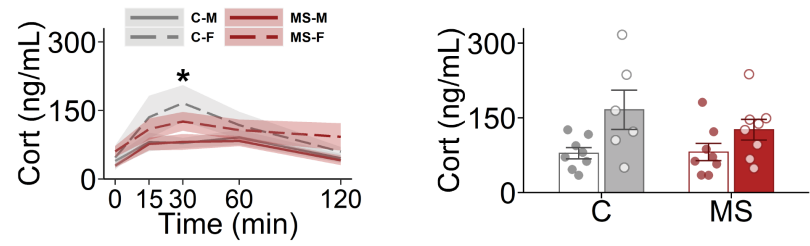

Fig. 4. Effect of MS on adult sociability and anxiety-like behavior mostly mirror juvenile phenotypes. (A) Experimental timeline for the forced swim and blood corticosterone collection timeline. A 15-minute pretest was done on the day before the testing began (5-minute test). Blood was collected at baseline (T0), 15 minutes (T15), 30 minutes (T30), 60 minutes (T60) and 120 minutes (T120) after baseline. (B) Rearing and Sex effects were identified on several measures of the FST (top left: Immobility (s), Rearing: $F_{1,26}=5.98, p=0.022$, Sex: $F_{1,26}=49, p=1.8 \times 10^{-7}$, Rearing $\times$ Sex: $F_{1,26}=0.21, p=0.65$; top right: Lat to Imm (s), Rearing: $F_{1,27}=0.89, p=0.36$, Sex: $F_{1,27}=7.16$, $p=0.012$, Rearing $\times$ Sex: $F_{1,27}=0.82, p=0.82$; middle left: Climbing (s), Rearing: $F_{1,27}=9.89, p=0.004$, Sex: $F_{1,27}=0.89, p=0.36$, Rearing $\times$ Sex: $F_{1,27}=3.15, p=0.08$; middle right: Struggling (s), Rearing: $F_{1,26}=3.57$, $p=0.70$, Sex: $F_{1,26}=30, p=9.6 \times 10^{-6}$, Rearing $\times$ Sex: $F_{1,26}=2.80$, $p=0.11$ ), with MS males spending more time immobile (Tukey's $p=0.018$ ), and females exhibiting shorter latencies to immobility (Tukey's $p=0.010$ ) but spending overall less time immobile (Tukey's $p=4.2 \times 10^{-7}$ ) and more time struggling (Tukey's $p=1.6 \times 10^{-5}$ ) compared to males. (C) Serum corticosterone levels revealed the expected increase immediately after FST but did not reveal a significant Rearing or Sex effects (Cort [ng/mL], Rearing: $F_{1,19}=0.15, p=0.70$ Sex: $F_{1,19}=1.93, p=0.18$, Time: $F_{9,819}=4.31, p=6.4 \times 10^{-10}$, Rearing $\times$ Sex: $F_{1,91}=0.012, p=0.92$, Rearing $\times$ Time: $F_{9,819}=1.82, p=0.62$, Sex $\times$ Time $: F_{9,819}=1.28, p=0.24$, Rearing $\times$ Sex $\times$ Time: $F_{9,819}=0.73$, $p=0.68$ ). Post hoc testing revealed corticosterone was significantly higher than baseline at T15, T30 and T60, but not T120 (Bonferroni, T15 $p=0.007$; T30 $p=2.9 \times 10^{-4} ;$ T60 $\left.p=3.8 \times 10^{-4}\right)$. Additionally, post hoc testing revealed a Sex effect at T30, with females having a significantly higher corticosterone level than males (Bonferroni, adjusted $p=0.04$ ). This Sex effect was confirmed on $2 \times 2$ ANOVA on the corticosterone levels at T30 (Rearing: $F_{1,26}=0.71, p=0.41$, Sex: $F_{1,26}=8.81, p=0.006$, Rearing $\times$ Sex: $F_{1,26}=0.91, p=0.35$ ). Bars represent means \pm SEM. Lines represent means. Shaded regions represent SEM. (Tukey's, ${ }^{*} p<0.05,{ }^{* *} p<0.01$ ).

(Tukey's $p=0.019$ ).

Next, we evaluated juvenile social behaviors. Social interaction and juvenile play were tested between P25 and P45. We first used the three-chambered SIT to quantify social preference toward an unfamiliar rat versus a novel object. No significant differences were found between $\mathrm{C}$ and 
MS (Rearing: $F_{1,67}=0.70, p=0.40$, Sex: $F_{1,67}=0.99$, $p=0.32$, Time: $F_{9,603}=4.93, p<1 \times 10^{-5}$, Rearing $\times$ Sex: $F_{1,67}=0.44, p=0.51$, Rearing $\times$ Time: $F_{9,603}=1.21$, $p=0.29$, Sex $\times$ Time: $F_{9,603}=0.99, p=0.45$, Rearing $\times$ Sex $\times$ Time: $\left.F_{9,603}=1.17, p=0.31\right)($ Fig. 2B, left). Both $\mathrm{C}$ and MS groups preferred the unfamiliar rat, spending $\sim 85 \%$ of their time in social exploration (Rearing: $F_{1,71}=0.036, p=0.85$, Sex: $F_{1,71}=0.34, p=0.56$, Rearing $\times$ Sex: $F_{1,71}=0.41, p=0.53$ ) (Fig $2 \mathrm{~B}$, right). Juvenile play was tested on 2 consecutive days twice, at P23-P24 and P37-P38.

A repeated-measures ANOVA on the duration of time spent engaging in play behavior revealed an interaction between Rearing and Sex (Rearing: $F_{1,25}=1.58, p=0.22$, Sex: $F_{1,25}=26, p=2.9 \times 10^{-5}$, Time: $F_{3,75}=7.24$, $p=2.5 \times 10^{-4}$, Rearing $\times$ Sex: $F_{1,25}=8.42, p=0.008$, Rearing $\times$ Time: $F_{3,75}=0.77, p=0.51$, Sex $\times$ Time: $F_{3,75}=1.73, p=0.17$, Rearing $\times$ Sex $\times$ Time: $F_{3,75}=$ $0.56, p=0.64$ ) (Fig. 2C, left). Bonferroni post-hoc test showed that the effects of Sex and its interaction with Rearing were due to more play behavior in the MS females compared to $\mathrm{C}$ females on the last day of testing (Bonferroni's $p=0.0015$ ). An analysis of the last day (Rearing: $F_{1,25}=4.36, p=0.047$, Sex: $F_{1,25}=17.1, p=3.5 \times 10^{-4}$, Rearing $\times$ Sex: $\left.F_{1,25}=1.65, p=0.21\right)$ alone confirmed this effect (Tukey's $p=1.9 \times 10^{-4}$ ) (Fig 2C, right).

We then assessed the effect of MS on anxiety-like behavior in the LD test (Fig. 2D). No significant differences between groups were observed in time spent in the light zone (Rearing: $F_{1,77}=0.24, p=0.63$, Sex: $F_{1,77}=7 \times 10^{-4}$, $p=0.98$, Rearing $\times$ Sex: $F_{1,77}=1.70, p=0.19$ ). However, there was a significant effect of Rearing was observed in the distance traveled in the light zone, with MS rats traveling a greater distance than $\mathrm{C}$ rats (Rearing: $F_{1,76}=11.3$, $p=0.001$, Sex: $F_{1,76}=0.007, p=0.94$, Rearing $\times$ Sex: $F_{1,76}=1.71, p=0.20$ ), and this this effect was largely driven by female rats (Tukey's $p=0.0039$ ). Additionally, both male and female MS rats also had significantly more entries into the light zone (Rearing: $F_{1,76}=11.3, p=0.001$, Sex: $F_{1,76}=0.007, p=0.94$, Rearing $\times$ Sex: $F_{1,76}=1.71, p=$ 0.20 , males Tukey's $p=0.019$, females Tukey's $p=0.010$ ), overall suggesting MS is associated with a lower anxiety-like phenotype.

\section{MS effects on sociability and anxiety-like behavior in the adult period mostly mirror juvenile phenotypes}

MS effects on sociability and anxiety-like behavior in the adult period mostly mirror juvenile phenotypes Social preference was examined again using SIT between P90 and P150 to evaluate for possible emergence of changes in sociability. Strong social preference was again seen across all groups. No significant effect of Rearing was observed (Rearing: $F_{1,98}=0.004, p=0.95$, Sex: $F_{1,98}=18.9, p=3.3 \times 10^{-5}$, Rearing $\times$ Sex: $F_{1,98}=0.014, p=0.91$ ), although a significant effect of Sex was identified, with males spending more time with an unfamiliar rat than females ( $80 \%$ vs $72 \%$, Tukey's $p=2.7 \times 10^{-5}$ ) (Fig. 3A, right). Time series analysis using repeated measures ANOVA revealed significant ef- fects of Sex and Time (Rearing: $F_{1,91}=0.011, p=0.92$, Sex: $F_{1,91}=21, p=1.4 \times 10^{-5}$, Time: $F_{9,819}=4.31$, $p=1.7 \times 10^{-5}$, Rearing $\times$ Sex: $F_{1,91}=0.012, p=0.92$, Rearing $\times$ Time: $F_{9,819}=1.82, p=0.62$, Sex $\times$ Time: $F_{9,819}=1.28, p=0.24$, Rearing $\times$ Sex $\times$ Time: $F_{9,819}=$ $0.73, p=0.68)$. Bonferroni post-hoc tests did not show significant differences between groups at any particular time but did show that the preference for the unfamiliar rat was significantly higher in the first minute compared to the rest of the 9 minutes of the experiment (Fig. 3A, left).

Anxiety-like behavior was reexamined using LD testing. A similar effect of Rearing (Rearing: $F_{1,97}=6.90, p=0.01$, Sex: $F_{1,97}=5.14, p=0.026$, Rearing $\times$ Sex: $F_{1,97}=2.26$, $p=0.14$ ) was observed as during the juvenile period, with MS males spending more time (Tukey's $p=0.021$ ) and traveling a longer distance (Rearing: $F_{1,99}=6.76, p=0.011$, Sex: $F_{1,99}=28.87, p=5.1 \times 10^{-7}$, Rearing $\times$ Sex: $F_{1,99}=$ $0.15, p=0.70$ ) in the light zone than $\mathrm{C}$ males (Tukey's $p=0.037$ ) (Fig. 3B). A significant effect of Sex was also observed (Rearing: $F_{1,97}=2.70, p=0.10$, Sex: $F_{1,97}=17.7$, $p=5.8 \times 10^{-5}$, Rearing $\times$ Sex: $\left.F_{1,97}=2.05, p=0.16\right)$, with females having shorter latency to the dark zone (Tukey's $p=0.0099$ ) but spending more time in (Tukey's $p=0.018$ ), and traveling longer distance in (Tukey's $p<3.1 \times 10^{-7}$ ) the light zone. However, no significant group differences were found in transitions to the light zone (Rearing: $F_{1,97}=0.86$, $p=0.36$, Sex: $F_{1,97}=0.021, p=0.89$, Rearing $\times$ Sex: $\left.F_{1,97}=0.045, p=0.83\right)$.

\section{MS is associated with long term negative coping-behavioral outcomes but not differences in blood corticosterone re- sponses}

The FST (Porsolt test) was used to evaluate effects of MS on coping behaviors. A 15-minute pretest period the day before the testing period (5-min) was used to habituate the rats (Fig. 4A). Additionally, baseline corticosterone was collected before testing began on Day 2 (T0), as well as 15 minutes (T15), 30 minutes (T30), 60 minutes (T60), and 120 minutes (T120) after the FST. The FST measures that were analyzed were: immobility time, latency to the first immobility state, climbing time, and struggling time.

A $2 \times 2$ ANOVA revealed significant effects of Rearing and Sex on immobility $\left(F_{1,26}=5.98, p=0.022\right.$, Sex: $F_{1,26}=49, p=1.8 \times 10^{-7}$, Rearing $\times$ Sex: $F_{1,26}=0.21$, $p=0.65$ ) (Fig. 4B). Post-hoc analysis revealed this effect was largely driven by MS males, which spent significantly more time immobile $(257 \pm 3 \mathrm{~s})$ than $\mathrm{C}$ males $(236 \pm 7 \mathrm{~s})$ (Tukey's $p=0.018$ ) and females (C: $158 \pm 16 \mathrm{~s}$, MS: $188 \pm$ $9 \mathrm{~s})$ (Fig. 4B). An effect of Sex but not Rearing was observed on the latency to the first immobility state (Rearing: $F_{1,27}=0.89, p=0.36$, Sex: $F_{1,27}=7.16, p=0.012$, Rearing $\times$ Sex: $F_{1,27}=0.82, p=0.82$ ), with females becoming immobile faster (Tukey's $p=0.010$ ).

Climbing behaviors, which can be indicative of a positive coping behavioral strategy, showed significant main effect of Rearing (Rearing: $F_{1,27}=9.89, p=0.004$, Sex: $F_{1,27}=0.89, p=0.36$, Rearing $\times$ Sex: $F_{1,27}=3.15$, $p=0.08$ ). Mirroring the results observed in immobility, 
bioRxiv preprint doi: https://doi.org/10.1101/2021.06.07.447289; this version posted June 7, 2021. The copyright holder for this preprint (which was not certified by peer review) is the author/funder, who has granted bioRxiv a license to display the preprint in perpetuity. It is made available under aCC-BY-NC-ND 4.0 International license.

A

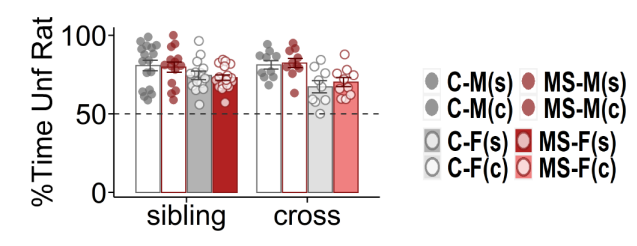

B
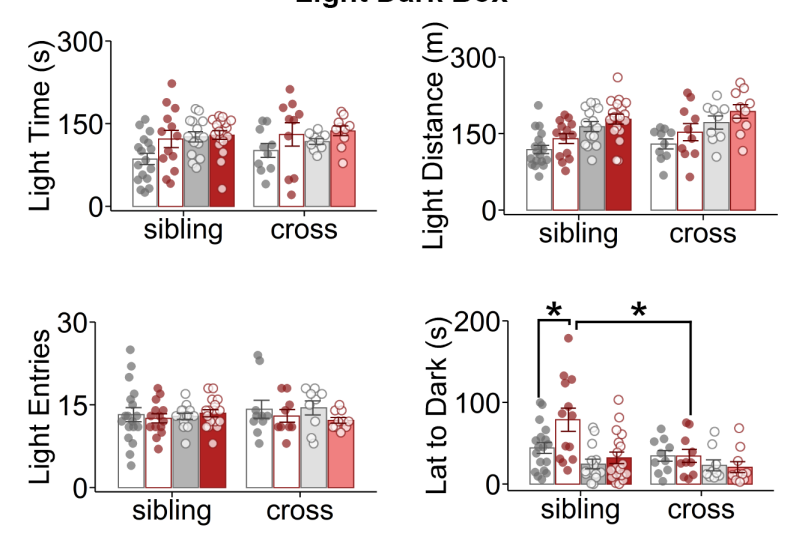

Fig. 5. Minimal effects observed as a function of post-weaning housing with sibling versus unfamiliar rat. (A)Post-weaning housing with sibling versus an cross-housing condition (control with MS) had no effect on SIT (\% Time Unf Rat: Rearing: $F_{1,94}=0.036, p=0.85$, Sex: $F_{1,94}=21, p=1.6 \times 10^{-5}$, Housing: $F_{1,94}=0.66, p=0.42$, Rearing $\times$ Sex: $F_{1,94}=0.027, p=0.87$, Rearing $\times$ Housing: $F_{1,94}=0.59, p=0.44$, Sex $\times$ Housing: $F_{1,94}=2.29$, $p=0.13$, Rearing $\times$ Sex $\times$ Housing: $F_{1,94}=0.067, p=0.79$ ). (B) Housing effects were also not observed in LD testing on time spent in, distance traveled in or entries into the light chamber, but a significant effect of Housing was observed on latency to enter the dark zone of the LD test (top left: Light Time (s): Rearing: $F_{1,93}=6.53, p=0.012$, Sex: $F_{1,93}=4.16, p=0.044$, Housing: $F_{1,93}=$ $0.45, p=0.50$, Rearing $\times$ Sex: $F_{1,93}=1.54, p=0.22$, Rearing $\times$ Hous ing: $F_{1,93}=0.066, p=0.79$, Sex $\times$ Housing: $F_{1,93}=0.51, p=0.48$, Rearing $\times$ Sex $\times$ Housing: $F_{1,93}=0.47, p=0.49$; top right: Light Distance $(\mathrm{m})$ : Rearing: $F_{1,95}=6.51, p=0.042$, Sex: $F_{1,95}=27, p=3.7 \times 10^{-5}$, Housing: $F_{1,95}=2.13, p=0.15$, Rearing $\times$ Sex: $F_{1,95}=0.066, p=0.79$, Rearing $\times$ Housing: $F_{1,95}=0.077, p=0.78$, Sex $\times$ Housing: $F_{1,95}=2.0 \times 10^{-4}$, $p=0.99$, Rearing $\times$ Sex $\times$ Housing: $F_{1,95}=0.030, p=0.86$; lower left: Light Entries, Rearing: $F_{1,93}=1.37, p=0.25$, Sex: $F_{1,93}=2.0 \times 10^{-4}, p=0.99$, Housing: $F_{1,93}=0.30, p=0.59$, Rearing $\times$ Sex: $F_{1,93}=0.002, p=0.96$, Rearing $\times$ Housing: $F_{1,93}=1.21, p=0.28$, Sex $\times$ Housing: $F_{1,93}=0.15$, $p=0.70$, Rearing $\times$ Sex $\times$ Housing: $F_{1,93}=0.54, p=0.46$; Lat to Dark (s): Rearing: $F_{1,94}=2.64, p=0.11$, Sex: $F_{1,94}=14.2, p=2.9 \times 10^{-4}$, Housing: $F_{1,94}=7.58, p=0.007$, Rearing $\times$ Sex: $F_{1,94}=1.44, p=0.23$, Rearing $\times$ Housing: $F_{1,94}=3.33, p=0.07$, Sex $\times$ Housing: $F_{1,94}=2.28$, $p=0.09$, Rearing $\times$ Sex $\times$ Housing: $F_{1,94}=1.01, p=0.32$ ). Fam, familiar; Unf, unfamiliar; Lat, latency; Light, light zone; Dark, dark zone. Bars represent means \pm SEM. Lines represent means. Shaded regions represent SEM. (Tukey's, $\left.{ }^{*} p<0.05,{ }^{* *} p<0.01\right)$.

this effect was driven mainly by MS males spending less time climbing compared with $\mathrm{C}$ males $(13.9 \pm 4.0 \mathrm{~s}$ versus $60.5 \pm 12.4 \mathrm{~s}$, respectively), as confirmed by a planned post-hoc testing (Tukey's $p=0.0050$ ). Struggling only revealed a significant effect of Sex (Rearing: $F_{1,26}=3.57$, $p=0.70$, Sex: $F_{1,26}=30, p=9.6 \times 10^{-6}$, Rearing $\times$ Sex: $F_{1,26}=2.80, p=0.11$ ), with female rats spending more time struggling than male rats (Tukey's $p=1.6 \times 10^{-5}$ ).

Above-described MS effects on FST are unlikely to be mediated by differences in stress-hormones, as no significant differences were identified on blood corticosterone levels except for Time (Rearing: $F_{1,19}=0.15, p=0.70$ Sex: $F_{1,19}=$ $1.93, p=0.18$, Time : $F_{9,819}=4.31, p=6.4 \times 10^{-10}$, Rearing $\times$ Sex: $F_{1,91}=0.012, p=0.92$, Rearing $\times$ Time $: F_{9,819}=1.82, p=0.62$, Sex $\times$ Time $: F_{9,819}=1.28$, $p=0.24$, Rearing $\times$ Sex $\times$ Time $: F_{9,819}=0.73, p=0.68$ ), which revealed corticosterone concentrations to increase during the FST compared to baseline (T0), except at T120 (Bonferroni, adjusted p, T15, $p=0.007$; T30 $p=2.9 \times 10^{-4}$; T60 $\left.p=3.8 \times 10^{-4}\right)$ and to decrease between T30, T60 and T120 (Bonferroni, adjusted $p$, T60, $p=0.016$; T120 $p=0.042$ ).

Post hoc analyses also revealed a significant Sex effect at $30 \mathrm{~min}$, with females having significantly higher corticosterone levels compared to males (Bonferroni, adjusted $p=0.04)$. This was confirmed by a $2 \times 2$ ANOVA on the corticosterone levels at this timepoint (Rearing: $F_{1,26}=0.71$, $p=0.41$, Sex: $F_{1,26}=8.81, p=0.006$, Rearing $\times$ Sex: $\left.F_{1,26}=0.91, p=0.35\right)$.

\section{Minimal effects observed as a function of post-weaning housing with sibling versus unfamiliar rat}

Post-weaning housing conditions can play a pivotal role in neurodevelopment (Smith et al., 1997) and potentially interact with preweaning MS. We therefore investigated whether adult behavioral outcomes were influenced by post-weaning housing with sibling versus unfamiliar rat from a crosshousing condition (control with maternally separated). No effects of Housing were observed on the SIT (Rearing: $F_{1,94}=0.036, p=0.85$, Sex: $F 1,94=21, p=1.6 \times$ $10^{-5}$, Housing: $F_{1,94}=0.66, p=0.42$, Rearing $\times$ Sex: $F_{1,94}=0.027, p=0.87$, Rearing $\times$ Housing: $F_{1,94}=0.59$, $p=0.44$, Sex $\times$ Housing: $F_{1,94}=2.29, p=0.13$, Rearing $\times$ Sex $\times$ Housing: $\left.F_{1,94}=0.067, p=0.79\right)($ Fig $5 \mathrm{~A})$. Housing effects were also not observed in LD testing on time spent in (Rearing: $F_{1,93}=6.53, p=0.012$, Sex: $F_{1,93}=$ $4.16, p=0.044$, Housing: $F_{1,93}=0.45, p=0.50$, Rearing $\times$ Sex: $F_{1,93}=1.54, p=0.22$, Rearing $\times$ Housing: $F_{1,93}=0.066, p=0.79$, Sex $\times$ Housing: $F_{1,93}=0.51$, $p=0.48$, Rearing $\times$ Sex $\times$ Housing: $F_{1,93}=0.47, p=$ 0.49 ), distance traveled in (Rearing: $F_{1,95}=6.51, p=0.012$, Sex: $F_{1,95}=27, p=1.2 \times 10^{-6}$, Housing: $F_{1,95}=2.13$, $p=0.15$, Rearing $\times$ Sex: $F_{1,95}=0.066, p=0.79$, Rearing $\times$ Housing: $F_{1,95}=0.077, p=0.78$, Sex $\times$ Housing : $F_{1,95}=2.0 \times 10^{-4}, p=0.99$, Rearing $\times$ Sex $\times$ Housing : $\left.F_{1,95}=0.030, p=0.86\right)$ or entries into the light chamber (Rearing: $F_{1,93}=1.37, p=0.25$, Sex: $F_{1,93}=2.0 \times 10^{-4}$, $p=0.99$, Housing: $F_{1,93}=0.30, p=0.59$, Rearing $\times$ Sex: $F_{1,93}=0.002, p=0.96$, Rearing $\times$ Housing: $F_{1,93}=1.21$, $p=0.28$, Sex $\times$ Housing: $F_{1,93}=0.15, p=0.70$, Rearing $\times$ Sex $\times$ Housing: $\left.F_{1,93}=0.54, p=0.46\right)$. A significant effect of Housing was observed on latency to enter the dark zone of the LD test (Rearing: $F_{1,94}=2.64, p=0.11$, Sex: $F_{1,94}=14.2, p=2.9 \times 10^{-4}$, Housing: $F_{1,94}=7.58$, $p=0.007$, Rearing $\times$ Sex: $F_{1,94}=1.44, p=0.23$, Rearing $\times$ Housing: $F_{1,94}=3.33, p=0.07$, Sex $\times$ Housing: $F_{1,94}=2.28, p=0.09$, Rearing $\times$ Sex $\times$ Housing: $F_{1,94}=1.01, p=0.32$ ) (Fig. $5 \mathrm{~B}$ ). Post-hoc tests revealed that MS males who were sibling-housed had longer 
bioRxiv preprint doi: https://doi.org/10.1101/2021.06.07.447289; this version posted June 7, 2021. The copyright holder for this preprint (which was not certified by peer review) is the author/funder, who has granted bioRxiv a license to display the preprint in perpetuity. It is made available under aCC-BY-NC-ND 4.0 International license.

latency to enter the dark zone compared with sibling-housed $\mathrm{C}$ males (Tukey's $p=0.023$ ) and MS male crossed-housed rats (Tukey's $p=0.020$ ).

A

\section{Social Interaction}

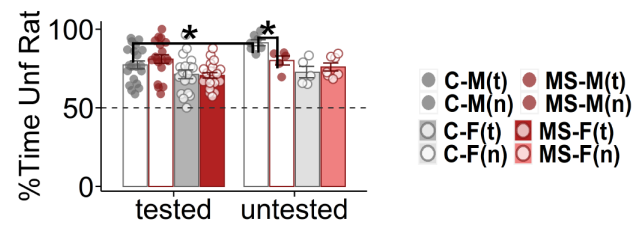

B

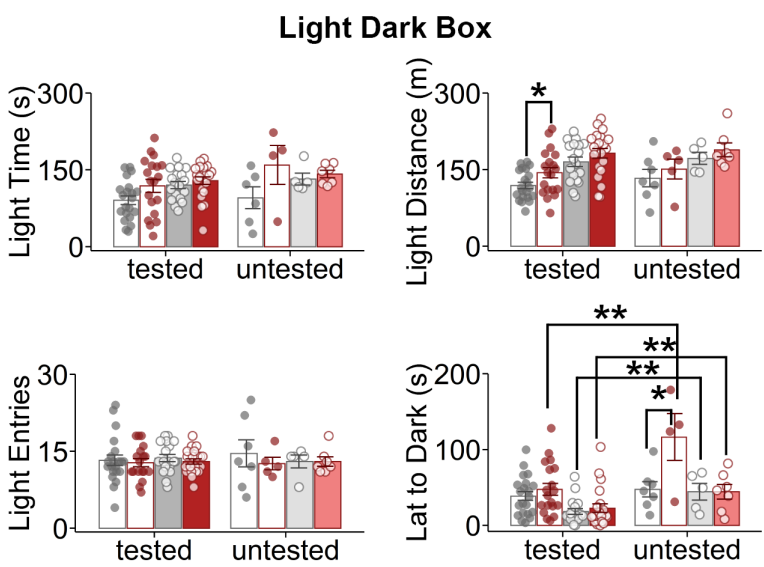

Fig. 6. Testing during the juvenile period influences adult behavioral outcomes in MS rats. (A)A significant effect of Sex and Prior Testing was observed in the SIT, with post-hoc analysis revealing untested $C$ males exhibited a stronger social preference toward an unfamiliar rat than previously tested $\mathrm{C}$ males and untested MS males. Prior Testing also was associated with more sociability in MS males compared to MS females (\% Time Unf Rat: Rearing: $F_{1,94}=0.27, p=0.61$, Sex: $F_{1,94}=16.8, p=8.8 \times 10^{-5}$, Testing: $F_{1,94}=4.37, p=0.039$, Rearing $\times$ Sex: $F_{1,94}=1.14, p=0.29$, Rearing $\times$ Testing: $F_{1,94}=1.37, p=0.25$, Sex $\times$ Testing: $F_{1,94}=0.46, p=0.50$, Rearing $\times$ Sex $\times$ Testing: $F_{1,94}=3.94$, $p=0.05)$. (B)LD testing was also influenced by prior testing, with significant effects observed by Rearing and Prior Testing, and interactions between Rearing and Sex, Rearing and Prior Testing, and Rearing, Sex, and Prior Testing on the latency to enter the dark zone in the LD test. Untested MS males took a significantly longer time to enter the dark zone than tested MS males. This was also true for untested female rats regardless of Rearing condition. (top left: Light Time (s): Rearing: $F_{1,93}=7.43, p=0.008$, Sex: $F_{1,93}=2.09, p=0.15$, Testing: $F_{1,93}=2.98, p=0.08$, Rearing $\times$ Sex: $F_{1,93}=3.30, p=0.07$, Rearing $\times$ Testing: $F_{1,93}=0.84, p=0.36$, Sex $\times$ Testing: $F_{1,93}=0.27, p=0.60$, Rearing $\times$ Sex $\times$ Testing: $F_{1,93}=0.73, p=0.39$; top right: Light Distance (m): Rearing: $F_{1,95}=4.23, p=0.042$, Sex: $F_{1,95}=18.8, p=3.7 \times 10^{-5}$, Testing: $F_{1,95}=0.88, p=0.35$, Rearing $\times$ Sex: $F_{1,95}=0.062, p=0.80$, Rearing $\times$ Testing: $F_{1,95}=0.038, p=0.84$, Sex $\times$ Testing : $F_{1,95}=0.045$, $p=0.83$, Rearing $\times$ Sex $\times$ Testing: $F_{1,95}=0.038, p=0.85$; lower left: Light Entries, Rearing: $F_{1,93}=0.78, p=0.38$, Sex: $F_{1,93}=0.022, p=0.88$, Testing: $F_{1,93}=0.019, p=0.89$, Rearing $\times$ Sex: $F_{1,93}=0.25, p=0.62$, Rearing $\times$ Testing: $F_{1,93}=0.058, p=0.81$, Sex $\times$ Testing: $F_{1,93}=0.27$, $p=0.61$, Rearing $\times$ Sex $\times$ Testing: $F_{1,93}=0.39, p=0.54$; Lat to Dark (s): Rearing: $F_{1,94}=9.06, p=0.003$, Sex: $F_{1,94}=19.5, p=2.7 \times 10^{-5}$, Testing: $F_{1,94}=21, p=1.4 \times 10^{-5}$, Rearing $\times$ Sex: $F_{1,94}=7.26, p=0.008$, Rearing $\times$ Testing: $F_{1,94}=4.16, p=0.044$, Sex $\times$ Testing: $F_{1,94}=1.21$, $p=0.28$, Rearing $\times$ Sex $\times$ Testing: $\left.F_{1,94}=5.54, p=0.021\right)$. Fam, familiar; Unf, unfamiliar; Lat, latency; Light, light zone; Dark, dark zone. Bars represent means \pm SEM. Lines represent means. Shaded regions represent SEM. (Tukey's, $\left.{ }^{*} p<0.05,{ }^{* *} p<0.01\right)$.

Testing during the juvenile period influences adult behavioral outcomes in MS rats
Test-retest reliability has been demonstrated to be low in rodent behavioral analysis (Andreatini and Bacellar, 2000) and significant habituation effects due to both repeat testing and cumulative handling have been observed (Bronstein et al., 1974; Gouveia and Hurst, 2017). Because not all rats were tested in the juvenile period, we therefore asked if juvenile testing influenced results of adult behavioral outcomes.

A significant effect of Sex and Prior Testing was observed in the SIT (Rearing: $F_{1,94}=0.27, p=0.61$, Sex: $F_{1,94}=16.8, p=8.9 \times 10^{-5}$, Testing: $F_{1,94}=4.37, p=$ 0.039 , Rearing $\times$ Sex: $F_{1,94}=1.14, p=0.29$, Rearing $\times$ Testing: $F_{1,94}=1.37, p=0.25$, Sex $\times$ Testing: $F_{1,94}=0.46, p=0.50$, Rearing $\times$ Sex $\times$ Testing: $F_{1,94}=$ $3.94, p=0.05$ ), with post-hoc analysis revealing untested $\mathrm{C}$ males exhibited a stronger social preference toward an unfamiliar rat than previously tested $\mathrm{C}$ males and untested MS males (Tukey's $p=0.0044$ ) (Fig. 6A). Prior Testing also was associated with more sociability in MS males compared to MS females (Tukey's $p=0.0023$ ).

LD testing was also influenced by prior testing, significant effects of Rearing and Prior Testing, and interactions between Rearing and Sex, Rearing and Prior Testing, and Rearing, Sex, and Prior Testing on the latency to enter the dark zone in the LD test (Rearing: $F_{1,94}=9.06, p=0.003$, Sex: $F_{1,94}=19.5, p=2.7 \times 10^{-5}$, Testing: $F_{1,94}=21$, $p=1.4 \times 10^{-5}$, Rearing $\times$ Sex: $F_{1,94}=7.26, p=0.008$, Rearing $\times$ Testing: $F_{1,94}=4.16, p=0.044$, Sex $\times$ Testing: $F_{1,94}=1.21, p=0.28$, Rearing $\times$ Sex $\times$ Testing: $F_{1,94}=5.54, p=0.021$ ) (Fig. 6B). MS male rats not previously tested on the LD test during the juvenile period took a significantly longer time to enter the dark zone than those tested during the juvenile period (Tukey's $p=0.0043$ ). This was also true for untested female rats regardless of Rearing condition, which took significantly less time to enter the dark zone (Tukey's $p=0.0025$ ).

\section{DISCUSSION}

Here, we developed a severe form of MS in rat, consisting of 6-hour daily separation from P2 through P21 at unpredictable times, with the goal of detailed characterization of biobehavioral profiles across the lifespan following maximal disruption of normal dam-pup interactions. In this comprehensive study we assessed maternal anxiety-like behavior, pup maternal odor preference, juvenile play behavior, sociability, juvenile and adult anxiety-like behaviors, stress coping, and glucocorticoid stress responses. We also addressed sibling versus cross-housing conditions and the effects of repeated testing as potential confounders. Overall, our study showed minimal effects on long-term behavioral outcomes.

\section{MS increases preference for maternal odor in male rats}

Our MS paradigm increased maternal odor preference in recently weaned MS male but not female rats. These results are consistent with a prior study showing the preference for odors associated with the dam to be enhanced by early life adversity (Raineki et al., 2010) and might be indicative of conditioned enhanced attachment to neglectful caregiving. Addi- 
tionally, in a mouse model of MS, it was found that control mice prefer maternal odor initially (P10), but that this attraction begins to weaken as the mice age (P14). In contrast, this weakening did not occur in MS mice, which preferred their maternal odors both at P10 and at P14 (Thomas et al., 2010). However, neither of these studies differentiated between male and female behavior, making them difficult to compare to our sex-specific findings.

\section{MS does not influence social preference but does increase play behavior in juvenile females}

Contrary to a number of reports showing decreased sociability following MS (Maciag, 2002; Tsuda et al., 2011; Farrell et al., 2016), social interaction testing during the juvenile and adult periods revealed no differences between groups in our model. All rats preferred to spend time in the chamber with an unfamiliar rat over a novel object, and this preference was strongest during the juvenile period.

However, a small and sex-specific difference in sociability was seen in juvenile play behavior, with MS females spending significantly more time playing than $\mathrm{C}$ female on the last day of testing (P38). Others who have tested juvenile play in MS-exposed rodents have found mixed results, with some groups finding no differences (Bodensteiner et al., 2014) and others finding an increase in aggressive play fighting (boxing) behaviors in female rats (Zimmerberg and Sageser, 2011). Although our MS female finding suggests enhanced propensity for social interaction, it might also reflect diminished ability to control social interactions. Interestingly, such an absence of social approach regulation has been seen in Romanian orphans (Kaler and Freeman, 1994; Chisholm, 1998).

\section{MS decreases anxiety-like behavior across the lifespan}

Many studies have demonstrated that MS increases anxietylike behavior as assessed in the open field and EPM tests in adulthood (Daniels et al., 2004; Cao et al., 2016; Shin et al., 2016; Bondar et al., 2018). Yet, negative (Millstein and Holmes, 2007), opposing (Leon Rodriguez and Duenas, 2013), or mixed effects (Markostamou et al., 2016; Dandi et al., 2018) have also been reported. Similarly, on the LD test, some found MS-induced deficits in juvenile rats (Chocyk et al., 2013) and adult rats (Wang et al., 2012), while others found a decrease in anxiety-like behavior in adult rats (Zhang et al., 2014) and still others found no effects (Tsuda and Ogawa, 2012). In our model, while absolute differences were modest, MS was overall associated with decreased anxiety-like behaviors on the LD test during both juvenile and adult periods. Housing condition played a role, with sibling-housing offering a small but significant additional protection against anxiety-like behavior in adult MS male rats.

\section{MS negatively impacts coping behaviors in MS male rats}

Our only result consistent with our initial hypothesis was on the FST, where MS male rats showed increased despair behaviors (immobility) and decreased coping behaviors (climbing). Notably, MS-driven effects in males were unlikely to be related to weight differences as MS male rats weighed less than $\mathrm{C}$ male rats in adulthood, which would predict more ability to climb. It is well-established that early-life stressors, especially as modeled through MS, are a risk factor for developing depressive-like behaviors (Lee et al., 2007; Marais et al., 2008; Bian et al., 2015; Amiri et al., 2016; Masrour et al., 2018; Ruiz et al., 2018).

Parameters such as immobility are measures of depressive-like or coping behaviors and are sensitive to antidepressant treatment (Porsolt et al., 1977). Our results are in line with previous studies showing MS rats display decreased coping behaviors on the FST (Veenema et al., 2006; Desbonnet et al., 2010; Bian et al., 2015; Amiri et al., 2016; Genty et al., 2018; Masrour et al., 2018; Ruiz et al., 2018). Additionally, and somewhat unexpectedly (Kokras et al., 2015), our results also showed strong sexually dimorphic behavior on the FST, with females spending overall less time immobile and more time struggling compared to males, indicating better coping strategies.

\section{MS does not affects glucocorticoid responses to stress}

As with most endpoints, MS has been associated with increased (Rincel et al., 2016; Ruiz et al., 2018), decreased (Biggio et al., 2018), or no effect (Rana et al., 2016) on corticosterone levels. When analyzing hypothalamicpituitary-adrenal (HPA)-axis reactivity, the results have also been mixed, although a majority of studies have found increased reactivity (Lajud et al., 2012). In our study, there was no significant effect of MS on either basal or stress-induced serum corticosterone levels. However, as widely reported in the literature (Babb et al., 2013; Albrechet-Souza et al., 2020), we did observe a higher corticosterone peak response in female rats, correlating with the increased female struggling time observed in the FST.

\section{Conclusion}

Our results further highlight the complex landscape of the rodent MS literature, which contains reports of both negative (Stanton et al., 1988; Kambali et al., 2019), positive (Zhang et al., 2014; Lundberg et al., 2017a) and null (Lehmann et al., 2000) effects of MS on future biobehavioral profiles. These conflicting findings are like due to the exact experimental design, including rodent species and strain, housing conditions, duration and exact time in the diurnal cycle for the separation, developmental period during which separation occurs, whether or not separation also extends to siblings, and post-weaning housing conditions.

It is interesting to note other studies employing prolonged MS paradigm from P1/P2 to P21 also have found minimal (Lundberg et al., 2017b) or positive behavioral effects (McIntosh et al., 1999), while most studies reporting negative outcomes use separation that ends around P14. The developing HPA axis in the rat undergoes a stereotypic process of a stress hyporesponsive period (SHRP) between P4 and P14, during which corticosterone responses are minimal or non-existent (Levine, 2001). Interestingly, MS-induced changes in dendritic spines in the anterior cingulate cortex, a key prefrontal region involved in emotional regulation, show 
bioRxiv preprint doi: https://doi.org/10.1101/2021.06.07.447289; this version posted June 7, 2021. The copyright holder for this preprint (which was not certified by peer review) is the author/funder, who has granted bioRxiv a license to display the preprint in perpetuity. It is made available under aCC-BY-NC-ND 4.0 International license.

distinct patterns depending on timing of the exposure, with decreased spine density in MS prior to SHRP, no changes in dendritic spines with MS during the SHRP and increases in dendritic spines with MS after the SHRP (Bock et al., 2005). Therefore, it is conceivable that our protocol led to initial deleterious neurocircuit changes during the first phase, with compensatory mechanisms developing during the later phase to ameliorate long-term maladaptive consequences.

\section{ACKNOWLEDGEMENTS}

This work was sponsored by generous donations from Fleur Fairman, John and Rainy Erwin, and Einhorn Collaborative.

\section{Bibliography}

L. Albrechet-Souza, C. L. Schratz, and N. W. Gilpin. Sex differences in traumatic stress reactivity in rats with and without a history of alcohol drinking. Biol Sex Differ, 11(1):27, 2020. ISSN 2042-6410 (Electronic) 2042-6410 (Linking). doi: 10.1186/s13293-020-00303-w. URL https://www.ncbi.nlm.nih.gov/pubmed/32393336.

S. Amiri, H. Amini-Khoei, A. Mohammadi-Asl, S. Alijanpour, A. Haj-Mirzaian, M. Rahimi-Balaei, A. Razmi, C. O. Olson, M. Rastegar, M. Mehdizadeh, and M. R. Zarrindast. Involvement of $\mathrm{d} 1$ and $\mathrm{d} 2$ dopamine receptors in the antidepressant-like effects of selegiline in maternal separation model of mouse. Physiol Behav, 163:107-114, 2016. ISSN 1873507X (Electronic) 0031-9384 (Linking). doi: 10.1016/j.physbeh.2016.04.052. URL https: //www.ncbi.nlm.nih.gov/pubmed/27143252.

R. Andreatini and L. F. S. Bacellar. Animal models: Trait or state measure? the test retest reliability of the elevated plus-maze and behavioral despair. Progress in NeuroPsychopharmacology and Biological Psychiatry, 24(4):549-560, 2000. ISSN 02785846. doi: 10.1016/s0278-5846(00)00092-0.

A. E. Arrant, N. L. Schramm-Sapyta, and C. M. Kuhn. Use of the light/dark test for anxiety in adult and adolescent male rats. Behav Brain Res, 256:119-27, 2013. ISSN 0166-4328. doi: 10.1016/j.bbr.2013.05.035. URL https://www.ncbi.nlm.nih.gov/pmc/articles/ PMC4119594/pdf/nihms586426.pdf.

J. A. Babb, C. V. Masini, H. E. Day, and S. Campeau. Sex differences in activated corticotropinreleasing factor neurons within stress-related neurocircuitry and hypothalamic-pituitaryadrenocortical axis hormones following restraint in rats. Neuroscience, 234:40-52, 2013. ISSN 1873-7544 (Electronic) 0306-4522 (Linking). doi: 10.1016/j.neuroscience.2012.12.051. URL https://www.ncbi.nlm.nih.gov/pubmed/23305762.

A. Baudin, K. Blot, C. Verney, L. Estevez, J. Santamaria, P. Gressens, B. Giros, S. Otani, V. Dauge, and $L$. Naudon. Maternal deprivation induces deficits in temporal memory and cognitive flexibility and exaggerates synaptic plasticity in the rat medial prefrontal cortex. Neurobiol Learn Mem, 98(3):207-14, 2012. ISSN 1095-9564 (Electronic) 1074-7427 (Linking). doi: 10.1016/j. nlm.2012.08.004. URL https://www.ncbi.nlm.nih.gov/pubmed/22922490.

B. L. Beverly, T. M. McGuinness, and D. J. Blanton. Communication and academic challenges in early adolescence for children who have been adopted from the former soviet union. Language, Speech, and Hearing Services in Schools, 39(3):303-313, 2008. ISSN 0161-1461 1558-9129. doi: 10.1044/0161-1461(2008/029).

Y. Bian, L. Yang, Z. Wang, Q. Wang, L. Zeng, and G. Xu. Repeated three-hour maternal separation induces depression-like behavior and affects the expression of hippocampal plasticityrelated proteins in c57bl/6n mice. Neural Plast, 2015:627837, 2015. ISSN 1687-5443 (Electronic) 1687-5443 (Linking). doi: 10.1155/2015/627837. URL https://www.ncbi.nlm. nih.gov/pubmed/26798520.

F. Biggio, G. Talani, V. Locci, M. G. Pisu, G. Boero, B. Ciarlo, D. R. Grayson, and M. Serra Low doses of prenatal ethanol exposure and maternal separation alter hpa axis function and ethanol consumption in adult male rats. Neuropharmacology, 131:271-281, 2018. ISSN 1873-7064 (Electronic) 0028-3908 (Linking). doi: 10.1016/j.neuropharm.2017.12.005. URL https://www.ncbi.nlm.nih.gov/pubmed/29223527.

J. Bock, M. Gruss, S. Becker, and K. Braun. Experience-induced changes of dendritic spine densities in the prefrontal and sensory cortex: correlation with developmental time windows. Cereb Cortex, 15(6):802-8, 2005. ISSN 1047-3211 (Print) 1047-3211 (Linking). doi: 10.1093/ cercor/bhh181. URL https://www.ncbi.nlm.nih.gov/pubmed/15371297.

K. J. Bodensteiner, N. Christianson, A. Siltumens, and J. Krzykowski. Effects of early maternal separation on subsequent reproductive and behavioral outcomes in male rats. J Gen Psy chol, 141(3):228-46, 2014. ISSN 1940-0888 (Electronic) 0022-1309 (Linking). doi: 10.1080/ 00221309.2014.897215. URL https://www.ncbi.nlm.nih.gov/pubmed/24940813.

N. P. Bondar, A. A. Lepeshko, and V. V. Reshetnikov. Effects of early-life stress on social and anxiety-like behaviors in adult mice: Sex-specific effects. Behav Neurol, 2018:1538931, 2018. ISSN 1875-8584 (Electronic) 0953-4180 (Linking). doi: 10.1155/2018/1538931. URL https : //www.ncbi.nlm.nih.gov/pubmed/29619126.

J. Bowlby. Disruption of affectional bonds and its effects on behavior. Journal of Contemporary Psychotherapy, 2(2):75-86, 1970. ISSN 0022-0116 1573-3564. doi: 10.1007/bf02118173.

J. Bowlby. Attachment and loss: retrospect and prospect. Am J Orthopsychiatry, 52(4):664-678, 1982. ISSN 0002-9432 (Print) 0002-9432 (Linking). doi: 10.1111/j.1939-0025.1982.tb01456.x. URL https://www.ncbi.nlm.nih.gov/pubmed/7148988.

P. M. Bronstein, H. Neiman, F. D. Wolkoff, and M. J. Levine. The development of habituation in the rat. Animal Learning and Behavior, 2(2):92-96, 1974. ISSN 0090-4996 1532-5830. doi: 10.3758/bf03199129.

C. Caldji, J. Diorio, and M. J. Meaney. Variations in maternal care in infancy regulate the development of stress reactivity. Biological Psychiatry, 48(12):1164-1174, 2000. ISSN 00063223. doi: 10.1016/s0006-3223(00)01084-2.
B. Cao, J. Wang, X. Zhang, X. Yang, D. C. Poon, B. Jelfs, R. H. Chan, J. C. Wu, and Y. Li. Impairment of decision making and disruption of synchrony between basolateral amygdala and anterior cingulate cortex in the maternally separated rat. Neurobiol Learn Mem, 136:7485, 2016. ISSN 1095-9564 (Electronic) 1074-7427 (Linking). doi: 10.1016/j.nlm.2016.09.015. URL https://www.ncbi.nlm.nih.gov/pubmed/27664716.

K. Chisholm. A three year follow-up of attachment and indiscriminate friendliness in children adopted from romanian orphanages. Child Development, 69(4):1092-1106, 1998. ISSN 00093920. doi: 10.1111/j.1467-8624.1998.tb06162.x.

A. Chocyk, B. Bobula, D. Dudys, A. Przyborowska, I. Majcher-Maslanka, G. Hess, and K. Wedzony. Early-life stress affects the structural and functional plasticity of the medial prefrontal cortex in adolescent rats. Eur J Neurosci, 38(1):2089-107, 2013. ISSN 1460-9568 (Electronic) 0953-816X (Linking). doi: 10.1111/ejn.12208. URL https://www . ncbi . nlm . nih . gov/pubmed/23581639.

H. T. Chugani, M. E. Behen, O. Muzik, C. Juhasz, F. Nagy, and D. C. Chugani. Local brain functional activity following early deprivation: a study of postinstitutionalized romanian orphans. Neuroimage, 14(6):1290-301, 2001. ISSN 1053-8119 (Print) 1053-8119 (Linking). doi: 10. 1006/nimg.2001.0917. URL https://www.ncbi.nlm.nih.gov/pubmed/11707085.

B. Costall, B. J. Jones, M. E. Kelly, R. J. Naylor, and D. M. Tomkins. Exploration of mice in a black and white test box: validation as a model of anxiety. Pharmacol Biochem Behav, 32(3): 777-85, 1989. ISSN 0091-3057 (Print) 0091-3057. doi: 10.1016/0091-3057(89)90033-6.

A. L. D'Agata, M. R. Sanders, D. J. Grasso, E. E. Young, X. Cong, and J. M. McGrath. Unpacking the burden of care for infants in the nicu. Infant Ment Health J, 38(2):306-317, 2017. ISSN 1097-0355 (Electronic) 0163-9641 (Linking). doi: 10.1002/imhj.21636. URL https : / /www . ncbi.nlm.nih.gov/pubmed/28236329.

E. Dandi, A. Kalamari, O. Touloumi, R. Lagoudaki, E. Nousiopoulou, C. Simeonidou, E. Spandou, and D. A. Tata. Beneficial effects of environmental enrichment on behavior, stress reactivity and synaptophysin/bdnf expression in hippocampus following early life stress. Int $J$ Dev Neurosci, 67:19-32, 2018. ISSN 1873-474X (Electronic) 0736-5748 (Linking). doi: 10.1016/ j.ijdevneu.2018.03.003. URL https://www.ncbi.nlm.nih.gov/pubmed/29545098.

W. M. Daniels, C. Y. Pietersen, M. E. Carstens, and D. J. Stein. Maternal separation in rats leads to anxiety-like behavior and a blunted acth response and altered neurotransmitter levels in response to a subsequent stressor. Metab Brain Dis, 19(1-2):3-14, 2004. ISSN 08857490 (Print) 0885-7490 (Linking). doi: 10.1023/b:mebr.0000027412.19664.b3. URL https : //www.ncbi.nlm.nih.gov/pubmed/15214501.

L. Desbonnet, L. Garrett, G. Clarke, B. Kiely, J. F. Cryan, and T. G. Dinan. Effects of the probiotic bifidobacterium infantis in the maternal separation model of depression. Neuroscience, 170(4):1179-88, 2010. ISSN 1873-7544 (Electronic) 0306-4522 (Linking). doi: 10.1016/j.neuroscience.2010.08.005. URL https://www.ncbi.nlm.nih.gov/pubmed/ 20696216.

M. R. Farrell, F. H. Holland, R. M. Shansky, and H. C. Brenhouse. Sex-specific effects of early life stress on social interaction and prefrontal cortex dendritic morphology in young rats. Behav Brain Res, 310:119-25, 2016. ISSN 1872-7549 (Electronic) 0166-4328 (Linking). doi: 10. 1016/j.bbr.2016.05.009. URL https://www.ncbi.nlm.nih.gov/pubmed/27180166.

J. Genty, M. Tetsi Nomigni, F. Anton, and U. Hanesch. The combination of postnatal maternal separation and social stress in young adulthood does not lead to enhanced inflammatory pain sensitivity and depression-related behavior in rats. PLoS One, 13(8):e0202599, 2018. ISSN 1932-6203 (Electronic) 1932-6203 (Linking). doi: 10.1371/journal.pone.0202599. URL https://www.ncbi.nlm.nih.gov/pubmed/30142161.

K. Gouveia and J. L. Hurst. Optimising reliability of mouse performance in behavioural testing: the major role of non-aversive handling. Sci Rep, 7:44999, 2017. ISSN 2045-2322 (Electronic) 2045-2322 (Linking). doi: 10.1038/srep44999. URL https : //www.ncbi.nlm.nih.gov/ pubmed/28322308.

M. A. Hofer. Studies on how early maternal separation produces behavioral change in young rats. Psychosomatic Medicine, 37(3):245-264, 1975. ISSN 0033-3174. doi: 10.1097/ 00006842-197505000-00003

M. A. Hofer. On the Relationship between Attachment and Separation Processes in Infancy, pages 199-219. 1983. ISBN 9780125587020. doi: 10.1016/b978-0-12-558702-0.50013-3.

M. A. Hofer. On the nature and consequences of early loss. Psychosomatic Medicine, 58(6): 570-581, 1996. ISSN 0033-3174. doi: 10.1097/00006842-199611000-00005.

M. A. Hofer and H. Weiner. Development and mechanisms of cardiorespiratory responses to maternal deprivation in rat pups. Psychosom Med, 33(4):353-62, 1971. ISSN 0033-3174 (Print) 0033-3174 (Linking). doi: 10.1097/00006842-197107000-00005. URL https : //www . ncbi.nlm.nih.gov/pubmed/5165240.

O. Kaidanovich-Beilin, T. Lipina, I. Vukobradovic, J. Roder, and J. R. Woodgett. Assessment of social interaction behaviors. J Vis Exp, (48), 2011. ISSN 1940-087X (Electronic) 1940087X (Linking). doi: 10.3791/2473. URL https://www.ncbi.nlm.nih.gov/pubmed/ 21403628.

J. H. Kaidbey, M. Ranger, M. M. Myers, M. Anwar, R. J. Ludwig, A. M. Schulz, J. L. Barone, J. Kolacz, and M. G. Welch. Early life maternal separation and maternal behaviour modulate acoustic characteristics of rat pup ultrasonic vocalizations. Sci Rep, 9(1):19012, 2019. ISSN 2045-2322 (Electronic) 2045-2322 (Linking). doi: 10.1038/s41598-019-54800-z. URL https : //www.ncbi.nlm.nih.gov/pubmed/31831757.

S. R. Kaler and B. J. Freeman. Analysis of environmental deprivation: Cognitive and socia development in romanian orphans. Journal of Child Psychology and Psychiatry, 35(4):769781, 1994. ISSN 0021-9630 1469-7610. doi: 10.1111/j.1469-7610.1994.tb01220.x.

M. Kalinichev, K. W. Easterling, P. M. Plotsky, and S. G. Holtzman. Long-lasting changes in stressinduced corticosterone response and anxiety-like behaviors as a consequence of neonatal maternal separation in long-evans rats. Pharmacology Biochemistry and Behavior, 73(1): 131-140, 2002. ISSN 00913057. doi: 10.1016/s0091-3057(02)00781-5.

M. Y. Kambali, K. Anshu, B. M. Kutty, R. S. Muddashetty, and T. R. Laxmi. Effect of early maternal separation stress on attention, spatial learning and social interaction behaviour. Exp Brain Res, 237(8):1993-2010, 2019. ISSN 1432-1106 (Electronic) 0014-4819 (Linking) doi: 10.1007/s00221-019-05567-2. URL https://www.ncbi.nlm.nih.gov/pubmed/ 31154461 .

J. Kentrop, C. R. Smid, E. J. M. Achterberg, I. M. H. van, M. J. Bakermans-Kranenburg, M. Joels, and R. van der Veen. Effects of maternal deprivation and complex housing on rat social 
bioRxiv preprint doi: https://doi.org/10.1101/2021.06.07.447289; this version posted June 7, 2021. The copyright holder for this preprint (which was not certified by peer review) is the author/funder, who has granted bioRxiv a license to display the preprint in perpetuity. It is made available under aCC-BY-NC-ND 4.0 International license.

behavior in adolescence and adulthood. Front Behav Neurosci, 12:193, 2018. ISSN 16625153 (Print) 1662-5153 (Linking). doi: 10.3389/fnbeh.2018.00193. URL https://www. ncbi.nlm.nih.gov/pubmed/30254573.

N. Kokras, K. Antoniou, H. G. Mikail, V. Kafetzopoulos, Z. Papadopoulou-Daifoti, and C. Dalla. Forced swim test: What about females? Neuropharmacology, 99:408-21, 2015. ISSN 18737064 (Electronic) 0028-3908 (Linking). doi: 10.1016/j.neuropharm.2015.03.016. URL https : //www.ncbi.nlm.nih.gov/pubmed/25839894.

J. M. Kreppner, M. Rutter, C. Beckett, J. Castle, E. Colvert, C. Groothues, A. Hawkins, T. G. O'Connor, S. Stevens, and E. J. S. Sonuga-Barke. Normality and impairment following profound early institutional deprivation: A longitudinal follow-up into early adolescence. Developmental Psychology, 43(4):931-946, 2007. ISSN 1939-0599 0012-1649. doi: 10.1037/ 0012-1649.43.4.931.

N. Lajud, A. Roque, M. Cajero, G. Gutierrez-Ospina, and L. Torner. Periodic maternal separation decreases hippocampal neurogenesis without affecting basal corticosterone during the stress hyporesponsive period, but alters hpa axis and coping behavior in adulthood. Psychoneuroendocrinology, 37(3):410-20, 2012. ISSN 1873-3360 (Electronic) 0306-4530 (Linking). doi: 10.1016/j.psyneuen.2011.07.011. URL https://www.ncbi.nlm.nih.gov/ pubmed/21862224

J. H. Lee, H. J. Kim, J. G. Kim, V. Ryu, B. T. Kim, D. W. Kang, and J. W. Jahng. Depressive behaviors and decreased expression of serotonin reuptake transporter in rats that experienced neonatal maternal separation. Neurosci Res, 58(1):32-9, 2007. ISSN 0168-0102 (Print) 0168-0102 (Linking). doi: 10.1016/j.neures.2007.01.008. URL https://www.ncbi.nlm. nih.gov/pubmed/17298851.

J. Lehmann, T. Stöhr, and J. Feldon. Long-term effects of prenatal stress experience and postnatal maternal separation on emotionality and attentional processes. Behavioural Brain Research, 107(1-2):133-144, 2000. ISSN 01664328. doi: 10.1016/s0166-4328(99)00122-9.

D. A. Leon Rodriguez and Z. Duenas. Maternal separation during breastfeeding induces gender-dependent changes in anxiety and the gaba-a receptor alpha-subunit in adult wistar rats. PLoS One, 8(6):e68010, 2013. ISSN 1932-6203 (Electronic) 1932-6203 (Linking). doi: 10.1371/journal.pone.0068010. URL https://www.ncbi.nlm.nih.gov/pubmed/ 23826356.

S. Levine. Primary social relationships influence the development of the hypothalamic-pituitary-adrenal axis in the rat. Physiology and Behavior, 73(3):255-260, 2001. ISSN 00319384. doi: 10.1016/s0031-9384(01)00496-6.

D. Liu, J. Diorio, B. Tannenbaum, C. Caldji, D. Francis, A. Freedman, S. Sharma, D. Pearson, P. M. Plotsky, and M. J. Meaney. Maternal care, hippocampal glucocorticoid receptors, and hypothalamic-pituitary-adrenal responses to stress. Science, 277(5332):1659-62, 1997. ISSN 0036-8075 (Print) 0036-8075 (Linking). doi: 10.1126/science.277.5332.1659. URL https://www.ncbi.nlm.nih.gov/pubmed/9287218.

R. J. Ludwig and M. G. Welch. Darwin's other dilemmas and the theoretical roots of emotional connection. Front Psychol, 10:683, 2019. ISSN 1664-1078 (Print) 1664-1078 (Linking). doi: 10. 3389/fpsyg.2019.00683. URL https://www.ncbi.nlm.nih.gov/pubmed/31031667.

S. Lundberg, M. Martinsson, I. Nylander, and E. Roman. Altered corticosterone levels and social play behavior after prolonged maternal separation in adolescent male but not female wistar rats. Horm Behav, 87:137-144, 2017a. ISSN 1095-6867 (Electronic) 0018-506X (Linking). doi: 10.1016/j.yhbeh.2016.11.016. URL https://www.ncbi.nlm.nih.gov/pubmed/ 27884596.

S. Lundberg, M. Martinsson, I. Nylander, and E. Roman. Altered corticosterone levels and social play behavior after prolonged maternal separation in adolescent male but not female wistar rats. Horm Behav, 87:137-144, 2017b. ISSN 1095-6867 (Electronic) 0018-506X (Linking). doi: 10.1016/j.yhbeh.2016.11.016. URL https://www.ncbi.nlm.nih.gov/pubmed/ 27884596.

C. Maciag. Effects of a non-peptide crf antagonist (dmp696) on the behavioral and endocrine sequelae of maternal separation. Neuropsychopharmacology, 26(5):574-582, 2002. ISSN 0893133X. doi: 10.1016/s0893-133x(01)00398-0.

J. Maniam and M. J. Morris. Long-term postpartum anxiety and depression-like behavior in mother rats subjected to maternal separation are ameliorated by palatable high fat diet. Behav Brain Res, 208(1):72-9, 2010. ISSN 1872-7549 (Electronic) 0166-4328 (Linking). doi: 10.1016/j. bbr.2009.11.005. URL https://www.ncbi.nlm.nih.gov/pubmed/19896506.

L. Marais, S. J. van Rensburg, J. M. van Zyl, D. J. Stein, and W. M. Daniels. Maternal separation of rat pups increases the risk of developing depressive-like behavior after subsequent chronic stress by altering corticosterone and neurotrophin levels in the hippocampus. Neurosci Res, 61(1):106-12, 2008. ISSN 0168-0102 (Print) 0168-0102 (Linking). doi: 10.1016/j.neures.2008. 01.011. URL https://www.ncbi.nlm.nih.gov/pubmed/18329744.

I. Markostamou, A. loannidis, E. Dandi, M. A. Mandyla, E. Nousiopoulou, C. Simeonidou, E. Spandou, and D. A. Tata. Maternal separation prior to neonatal hypoxia-ischemia: Impact on emotional aspects of behavior and markers of synaptic plasticity in hippocampus. Int $\mathrm{J}$ Dev Neurosci, 52:1-12, 2016. ISSN 1873-474X (Electronic) 0736-5748 (Linking). doi: 10.1016/j. ijdevneu.2016.04.002. URL https://www.ncbi.nlm.nih.gov/pubmed/27165447.

F. F. Masrour, M. Peeri, M. A. Azarbayjani, and M. J. Hosseini. Voluntary exercise during adolescence mitigated negative the effects of maternal separation stress on the depressive-like behaviors of adult male rats: Role of nmda receptors. Neurochem Res, 43(5):1067-1074, 2018. ISSN 1573-6903 (Electronic) 0364-3190 (Linking). doi: 10.1007/s11064-018-2519-6. URL https://www.ncbi.nlm.nih.gov/pubmed/29616445.

J. McIntosh, H. Anisman, and Z. Merali. Short- and long-periods of neonatal maternal separation differentially affect anxiety and feeding in adult rats: gender-dependent effects. Developmental Brain Research, 113(1-2):97-106, 1999. ISSN 01653806. doi: 10.1016/s0165-3806(99) 00005-x.

R. A. Millstein and A. Holmes. Effects of repeated maternal separation on anxiety- and depression-related phenotypes in different mouse strains. Neurosci Biobehav Rev, 31(1):317, 2007. ISSN 0149-7634 (Print) 0149-7634 (Linking). doi: 10.1016/j.neubiorev.2006.05.003. URL https://www.ncbi.nlm.nih.gov/pubmed/16950513.

J. Molet, P. M. Maras, S. Avishai-Eliner, and T. Z. Baram. Naturalistic rodent models of chronic early-life stress. Dev Psychobiol, 56(8):1675-88, 2014. ISSN 1098-2302 (Electronic) 0012 1630 (Linking). doi: 10.1002/dev.21230. URL https://www.ncbi.nlm.nih.gov/ pubmed/24910169.
Z. Mozaffari. The impact of early adversity on mental health in young adulthood: Findings from the Romanian Adoption Project. Thesis, 2018.

M. M. Myers, S. A. Brunelli, J. M. Squire, R. D. Shindeldecker, and M. A. Hofer. Maternal behavior of shr rats and its relationship to offspring blood pressures. Dev Psychobiol, 22(1): 29-53, 1989. ISSN 0012-1630 (Print) 0012-1630 (Linking). doi: 10.1002/dev.420220104. URL https://www.ncbi.nlm.nih.gov/pubmed/2912812.

A. P. Pesarico, S. G. Rosa, E. C. Stangherlin, A. C. Mantovani, G. Zeni, and C. W. Nogueira. 7fluoro-1,3-diphenylisoquinoline-1-amine reverses the reduction in self-care behavior induced by maternal separation stress in rats by modulating glutamatergic/gabaergic systems. J Psychiatr Res, 89:28-37, 2017. ISSN 1879-1379 (Electronic) 0022-3956 (Linking). doi: 10.1016/j. jpsychires.2017.01.013. URL https://www.ncbi.nlm.nih.gov/pubmed/28153643.

R. Porsolt, A. Bertin, and M. Jalfre. Behavioral despair in mice: a primary screening test for antidepressants. Archives internationales de pharmacodynamie et de therapie, 229(2):327, 1977. ISSN 0003-9780

C. Raineki, S. Moriceau, and R. M. Sullivan. Developing a neurobehavioral animal model of infant attachment to an abusive caregiver. Biol Psychiatry, 67(12):1137-45, 2010. ISSN 18732402 (Electronic) 0006-3223 (Linking). doi: 10.1016/j.biopsych.2009.12.019. URL https: //www.ncbi.nlm.nih.gov/pubmed/20163787.

S. Rana, P. C. Pugh, E. Katz, S. A. Stringfellow, C. P. Lin, J. M. Wyss, H. M. Stauss, C. R. White, S. M. Clinton, and I. A. Kerman. Independent effects of early-life experience and trait aggression on cardiovascular function. Am J Physiol Regul Integr Comp Physiol, 311 (2):R272-86, 2016. ISSN 1522-1490 (Electronic) 0363-6119 (Linking). doi: 10.1152/ajpregu. 00505.2015. URL https://www.ncbi.nlm.nih.gov/pubmed/27280432.

M. Ranger, T. B. Behring, J. H. Kaidbey, M. Anwar, A. B. Lipshutz, I. Mollicone, G. Hassan, K. Fasano, N. K. Hinz, R. J. Ludwig, M. M. Myers, M. G. Welch, and D. Dumitriu. Maternal separation affects fronto-cortical activity in rat pups during dam-pup interactions and behavioral transitions. bioRxiv, 2021. doi: 10.1101/2021.05.19.444831. URL https: //www.biorxiv.org/content/early/2021/05/21/2021.05.19.444831.

M. Rincel, A. L. Lepinay, P. Delage, J. Fioramonti, V. S. Theodorou, S. Laye, and M. Darnaudery. Maternal high-fat diet prevents developmental programming by early-life stress. Transl Psychiatry, 6(11):e966, 2016. ISSN 2158-3188 (Electronic) 2158-3188 (Linking). doi: 10.1038/tp.2016.235. URL https://www.ncbi.nlm.nih.gov/pubmed/27898075.

R. D. Romeo, A. Mueller, H. M. Sisti, S. Ogawa, B. S. McEwen, and W. G. Brake. Anxiety and fear behaviors in adult male and female c57bl/6 mice are modulated by maternal separation. Hormones and Behavior, 43(5):561-567, 2003. ISSN 0018506X. doi: 10.1016/s0018-506x(03)00063-1.

R. Ruiz, A. Roque, E. Pineda, P. Licona-Limon, J. Jose Valdez-Alarcon, and N. Lajud. Early life stress accelerates age-induced effects on neurogenesis, depression, and metabolic risk. Psychoneuroendocrinology, 96:203-211, 2018. ISSN 1873-3360 (Electronic) 0306-4530 (Linking). doi: 10.1016/j.psyneuen.2018.07.012. URL https://www.ncbi.nlm.nih.gov/ pubmed/30048914.

S. Y. Shin, S. H. Han, R. S. Woo, S. H. Jang, and S. S. Min. Adolescent mice show anxietyand aggressive-like behavior and the reduction of long-term potentiation in mossy fiber-ca3 synapses after neonatal maternal separation. Neuroscience, 316:221-31, 2016. ISSN 18737544 (Electronic) 0306-4522 (Linking). doi: 10.1016/j.neuroscience.2015.12.041. URL https : //www.ncbi.nlm.nih.gov/pubmed/26733385.

D. A. Slattery and J. F. Cryan. Using the rat forced swim test to assess antidepressant-like activity in rodents. Nat Protoc, 7(6):1009-14, 2012. ISSN 1750-2799 (Electronic) 1750-2799 (Linking). doi: 10.1038/nprot.2012.044. URL https://www.ncbi.nlm.nih.gov/pubmed/ 22555240

J. K. Smith, J. C. Neill, and B. Costall. Post-weaning housing conditions influence the behavioural effects of cocaine and d-amphetamine. Psychopharmacology (Berl), 131(1):23-33, 1997. ISSN 0033-3158 (Print) 0033-3158 (Linking). doi: 10.1007/s002130050261. URL https: //www.ncbi.nlm.nih.gov/pubmed/9181632.

M. E. Stanton, Y. R. Gutierrez, and S. Levine. Maternal deprivation potentiates pituitary-adrenal stress responses in infant rats. Behav Neurosci, 102(5):692-700, 1988. ISSN 0735-7044 (Print) 0735-7044. doi: 10.1037//0735-7044.102.5.692.

S. E. Stevens, E. J. Sonuga-Barke, J. M. Kreppner, C. Beckett, J. Castle, E. Colvert, C. Groothues, A. Hawkins, and M. Rutter. Inattention/overactivity following early severe institutional deprivation: presentation and associations in early adolescence. J Abnorm Child Psychol, 36(3):38598, 2008. ISSN 0091-0627 (Print) 0091-0627 (Linking). doi: 10.1007/s10802-007-9185-5. URL https://www.ncbi.nlm.nih.gov/pubmed/17965931.

N. R. Thomas, L. K. Fonken, M. E. LeBlanc, and C. A. Cornwell. Maternal separation alters social odor preference development in infant mice (mus musculus). J Comp Psychol, 124(3):295301, 2010. ISSN 1939-2087 (Electronic) 0021-9940 (Linking). doi: 10.1037/a0018896. URL https://www.ncbi.nlm.nih.gov/pubmed/20695661.

M. C. Tsuda and S. Ogawa. Long-lasting consequences of neonatal maternal separation on social behaviors in ovariectomized female mice. PLoS One, 7(3):e33028, 2012. ISSN 19326203 (Electronic) 1932-6203 (Linking). doi: 10.1371/journal.pone.0033028. URL https: //www.ncbi.nlm.nih.gov/pubmed/22412981.

M. C. Tsuda, N. Yamaguchi, and S. Ogawa. Early life stress disrupts peripubertal development of aggression in male mice. Neuroreport, 22(6):259-63, 2011. ISSN 1473-558X (Electronic) 0959-4965 (Linking). doi: 10.1097/WNR.0b013e328344495a. URL https://www.ncbi. nlm.nih.gov/pubmed/21403582

A. H. Veenema, A. Blume, D. Niederle, B. Buwalda, and I. D. Neumann. Effects of early life stress on adult male aggression and hypothalamic vasopressin and serotonin. Eur $\mathrm{J}$ Neurosci, 24 (6):1711-20, 2006. ISSN 0953-816X (Print) 0953-816X (Linking). doi: 10.1111/j.1460-9568. 2006.05045.x. URL https://www.ncbi.nlm.nih.gov/pubmed/17004935.

X. D. Wang, C. Labermaier, F. Holsboer, W. Wurst, J. M. Deussing, M. B. Muller, and M. V. Schmidt. Early-life stress-induced anxiety-related behavior in adult mice partially requires forebrain corticotropin-releasing hormone receptor 1. Eur J Neurosci, 36(3):2360-7, 2012. ISSN 1460-9568 (Electronic) 0953-816X (Linking). doi: 10.1111/j.1460-9568.2012.08148.x. URL https://www.ncbi.nlm.nih.gov/pubmed/22672268.

M. G. Welch. Calming cycle theory: the role of visceral/autonomic learning in early mother and infant/child behaviour and development. Acta Paediatr, 105(11):1266-1274, 2016. ISSN 1651-2227 (Electronic) 0803-5253 (Linking). doi: 10.1111/apa.13547. URL https ://www. 
bioRxiv preprint doi: https://doi.org/10.1101/2021.06.07.447289; this version posted June 7, 2021. The copyright holder for this preprint (which was not certified by peer review) is the author/funder, who has granted bioRxiv a license to display the preprint in perpetuity. It is made available under aCC-BY-NC-ND 4.0 International license.

ncbi.nlm.nih.gov/pubmed/27536908.

X. Xue, S. Shao, W. Wang, and F. Shao. Maternal separation induces alterations in reversal learning and brain-derived neurotrophic factor expression in adult rats. Neuropsychobiology, 68 (4):243-9, 2013. ISSN 1423-0224 (Electronic) 0302-282X (Linking). doi: 10.1159/000356188. URL https://www.ncbi.nlm.nih.gov/pubmed/24280707.

R. Yankelevitch-Yahav, M. Franko, A. Huly, and R. Doron. The forced swim test as a model of depressive-like behavior. J Vis Exp, (97), 2015. ISSN 1940-087X (Electronic) 1940087X (Linking). doi: 10.3791/52587. URL https://www.ncbi.nlm.nih.gov/pubmed/ 25867960.

X. Zhang, B. Wang, J. Jin, S. An, Q. Zeng, Y. Duan, L. Yang, J. Ma, and X. Cao. Early deprivation reduced anxiety and enhanced memory in adult male rats. Brain Res Bull, 108:44-50, 2014. ISSN 1873-2747 (Electronic) 0361-9230 (Linking). doi: 10.1016/j.brainresbull.2014.08.005. URL https://www.ncbi.nlm.nih.gov/pubmed/25157962.

Y. Zhang, X. Zhu, M. Bai, L. Zhang, L. Xue, and J. Yi. Maternal deprivation enhances behavioral vulnerability to stress associated with mir-504 expression in nucleus accumbens of rats. PLoS One, 8(7):e69934, 2013. ISSN 1932-6203. doi: 10.1371/journal.pone. 0069934. URL https://ww.ncbi.nlm.nih.gov/pme/articles/PMC3724734/ pdf/pone.0069934.pdf.

B. Zimmerberg and K. A. Sageser. Comparison of two rodent models of maternal separation on juvenile social behavior. Front Psychiatry, 2:39, 2011. ISSN 1664-0640 (Electronic) 16640640 (Linking). doi: 10.3389/fpsyt.2011.00039. URL https://www.ncbi.nlm.nih. gov/pubmed/21747771. 